\title{
An experimental analysis of evacuees' walking speeds under different rolling conditions of a ship
}

\author{
Xinjian Wanga, ${ }^{a}$, Zhengjiang Liu ${ }^{a, b}, Z^{2}$ aili Yang ${ }^{c, d}$, Sean Loughney ${ }^{c}$, Yanfu Wang, \\ Jin Wang ${ }^{\mathrm{c*}}$ \\ ${ }^{a}$ Navigation College, Dalian Maritime University, Dalian 116026, P.R. China \\ ${ }^{\mathrm{b}}$ Key Laboratory of Navigation Safety Guarantee of Liaoning Province, Dalian 116026, P.R. China \\ ${ }^{c}$ Liverpool Logistics, Offshore and Marine (LOOM) Research Institute, School of Engineering, \\ Liverpool John Moores University, L3 3AF, UK \\ ${ }^{\mathrm{d}}$ Transport Engineering College, Dalian Maritime University, Dalian 116026, P.R China \\ ${ }^{\mathrm{e}}$ College of Mechanical and Electronic Engineering, China University of Petroleum, Qingdao 266580, \\ P.R China
}

\begin{abstract}
During the emergency evacuation on passenger vessels, an individual's walking speed will be affected by the ship's rolling motions. It is necessary and beneficial to evaluate the effect of such motions on individuals' walking speeds in order to facilitate the evacuation and reduce the consequence of a maritime accident. In this study, we collected primary data from a series of walking experiments on-board a real ship to quantitatively evaluate the effect of different ship roll angular magnitudes on an individual's walking speed in two scenarios of flat terrains and staircases, respectively. It was found that on flat terrains, the ship's rolling motion results in the reduction of an individual's walking speed at a rate of $7 \%$ to $16 \%$. On a staircase, an individual's speed of walking up the staircases was reduced by approximately $5 \%$ due to the ship's rolling motion. The findings will contribute to the development of optimal evacuation routes on passenger ships. The used method can also be tailored to model the effect of the other dynamic environments on walking speeds at sea (e.g., on offshore platforms) and onshore (e.g., during earthquakes) to improve evacuation efficiency for disaster prevention.
\end{abstract}

Keywords: Safety evacuation, Ship safety, Individual walking speed, Passenger ship, Ship motion, Experimental analysis

\section{Introduction}

\footnotetext{
* Corresponding author: j.wang@ljmu.ac.uk (J. Wang)
} 
Over the past 20 years, the increased carrying capacity of passenger vessels due to the rapid development of new technologies has resulted in a potential high risk stake on the fatalities from maritime accidents (Huang et al., 2020; Sun et al., 2018b; Uğurlu et al., 2018; Wang et al., 2020b). Catastrophic maritime accidents have the potential to cause immense loss of life, especially when involving large passenger vessels (Fan et al., 2020; Montewka et al., 2014; Wang et al., 2021a; Xie et al., 2020a). For example, a fire broke out on the cruise ship "Diamond Princess" in 2006, causing one death and nine injuries (Xie et al., 2020b). The "Sewol" Ro-Ro passenger vessel which was capsized in 2014 caused 304 deaths, including 8 missing passengers (Wang et al., 2020a). The safety of passenger vessels has always been a major concern in the maritime industry (Fan et al., 2020; Uğurlu et al., 2018; Wang et al., 2021c).

To improve the safety level of passenger vessels, after several revisions and updates, the International Maritime Organization (IMO) issued the "Revised guidelines on evacuation analyses of the new and existing passenger ships" in 2016, which require evacuation analysis not only for Ro-Ro passenger ships but also for other passenger ships built on or after January 1st, 2020 (IMO, 2016; Wang et al., 2020a). Walking speed is an important parameter in evacuation analysis (Lee et al., 2004; Sun et al., 2018a; Wang et al., 2021b); it depends not only on the age, gender, height and mobility of passengers but also on the ship motion, listing and other external factors (Kim et al., 2019; Lee et al., 2004; Wang et al., 2021b). As shown in Fig. 1, a ship has 6 degrees of freedom in oceans, with the most common motions being roll and pitch. Since the ship's length is larger than its width, the roll angular magnitude of the ship are usually larger than the pitch one (Haaland et al., 2015; Walter et al., 2019). The effect of ship rolling motion on an individual's walking ability can be significant. It is evident that crew members' "swaying gait" will continue for a while after returning to land (Walter et al., 2017; Wang et al., 2021b). Different from the situation on land, passengers on-board have to evacuate from a listing or moving vessels in an emergency situation. This evacuation in a dynamic environment is substantially more difficult than that in a static 
one, which will reduce an individual's walking speed and greatly increase the total evacuation time. Therefore, when conducting evacuation simulation analysis on a ship, the change in an individual's walking speed with the ship's motion state must be considered (Kim et al., 2019; Wang et al., 2021b).

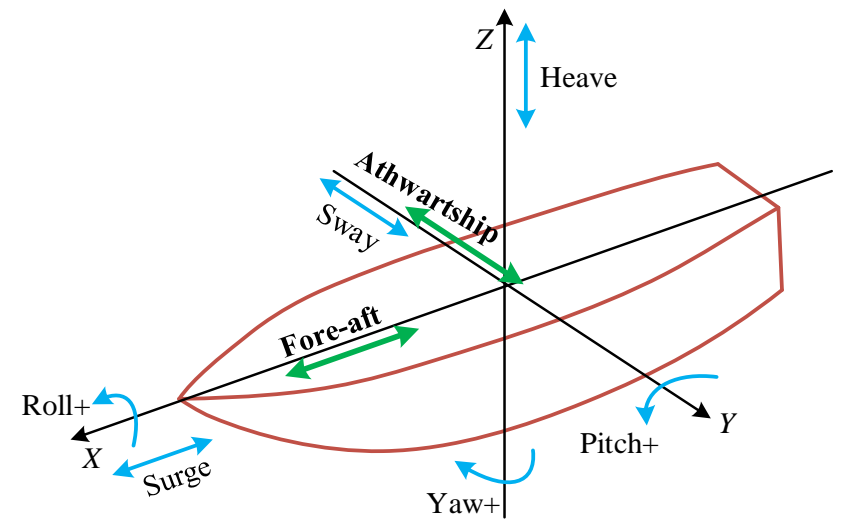

Fig. 1 Six degrees of freedom of ship motion in the ocean (Wang et al., 2021b)

There are 5 sections organized in this paper. Section 2 presents the previous studies of individuals' walking speeds during the ship emergency evacuation process. Section 3 describes how the experiments were carried out and what data was collected. Section 4 analyses the influence of different ship roll angular magnitudes on individuals' walking speeds on flat terrains and staircases, and the results were also compared with previous studies. Finally, conclusions are summarized in Section 5.

\section{Literature review}

Previous studies investigated individuals' walking speeds during ship listing or ship motion. Due to the high experimental cost and safety issues, they often had to use ship environment simulators or ship trial observations to study individuals' walking speeds. In a ship environment simulator experiment, Yoshida, et al. (2001) built a ship corridor simulator to test individuals' walking speeds under static inclination and dynamic motion. The results showed that the walking speeds of 19 male and 2 female individuals ranged from $1.23 \mathrm{~m} / \mathrm{s}$ to $1.25 \mathrm{~m} / \mathrm{s}$ without listing, and the walking speeds under rolling and pitching conditions were about $70 \%$ of those in an even level condition. Bles et al. (2002) carried out an experimental study on a ship motion 
simulator. The study revealed that the speed of walking up the staircases and down the staircases, for all age groups, was reduced by $40 \%$ and $30 \%$, respectively, and the dynamic ship motion reduced an individual's average walking speed by $15 \%$. Sun et al. (2018a; 2018b) used a ship corridor simulator to test the walking speeds of 17 students under the influence of a ship heeling, trimming, and both combined. They discovered that by considering the heeling angle and/or trim angle, the average individual walking speed can be greatly reduced. Compared with the trim angle, the heeling angle had less influence on the average individual walking speed (Sun et al., 2018a; Sun et al., 2018b). Galea et al. (Galea, 2012; Glen, 2004) had jointly established a Ship Evacuation Behaviour Assessment Facility (SHEBA), in which a series of experiments were carried out, and the experimental results were applied to the ship evacuation simulation software, maritime EXODUS (Galea, 2012; Glen, 2004). Based on the experimental results, German Lloyd's Register of Shipping proposed a model of the speed reduction ratio (i.e., the ratio of an individual's walking speed in the presence of a listing condition to the corresponding speed on flat terrain) to describe the effect of different heeling or trim angles on an individual's walking speed and applied the model to the ship evacuation software AENEAS (Meyer-König et al., 2007). However, the accuracy of the results by these means is always arguable given the fact that no simulators can $100 \%$ model and reflect the real ship operational environments in reality. As a result, the scientific evacuation solutions developed on the basis of such simulation based results could be error-prone.

Using ship trial observations, Lee et al. (2004) from Korea Research Institutes of Ships and Ocean Engineering (KRISO) employed a training ship of Korea Maritime University to test the walking speeds of 21 students (18 male and 3 female); they determined that the ship motion reduced an individual's walking speed by $10 \%$ to $20 \%$. Kwang et al. (2013) analysed the effect of ship motion on individuals' walking speeds by using ship berthing and sailing conditions and discovered that an individual's walking speed during berthing and sailing was $2.02 \mathrm{~m} / \mathrm{s}$ and $1.42 \mathrm{~m} / \mathrm{s}$, respectively. Due 
to ship motion, the walking speed decreased by $27.2 \%$. Wang et al. (2021b) conducted a series of walking experiments during training ship berthing and sailing conditions and determined that the ship rolling motion reduced individuals' normal walking speeds by $3.8 \%$ to $10.3 \%$ and individuals' fast walking speeds by $3.7 \%$ to $14.0 \%$ (Wang et al., 2021b). Walter et al. (2017; 2019) investigated the individual walking ability in different walking directions (athwartship and fore-aft) and two ship motion conditions (i.e., roll $>$ pitch and pitch $>$ roll); they discovered that when the rolling angular magnitude was larger than the magnitude of pitch motion, the maximum walkable distance in the specified path when walking along the short axis or athwartship axis of the ship was greater than that when walking along the long or fore-aft axis of the ship; when the magnitude of pitch motion was larger the that of roll, this relationship should be reversed (Haaland et al., 2015; Walter et al., 2017; Walter et al., 2019). As shown in Table 1, in the study of human walking speed during ship evacuation, the majority of the results were obtained based on a static ship environment simulator. In a limited amount of ship trial observations, researchers only carried out human walking experiments when the ship was berthing, anchoring or in a certain motion condition (e.g., with a rolling angular magnitude), and the variations of individuals' walking speeds in different ship motion states (roll angular magnitudes) were not explored.

To support, expand and verify the existing passenger ship evacuation model and simulation software and provide reliable empirical data for evacuation analysis, this study, for the first time, carried out a series of human walking experiments on the training ship "Yupeng" of Dalian Maritime University (DMU), China. Individuals' walking speeds on flat terrains and staircases were collected with reference to different roll angular magnitudes. The impact of ship rolling motion on an individual's walking speed, the differences between the athwartship and the fore-aft walking speeds, between the male and female walking speeds, between different decks were analysed, and the main findings on individuals' walking speeds are summarized in Fig. 2. 
Table 1 Comparison of the reviewed studies

\begin{tabular}{|c|c|c|c|c|c|}
\hline No. & Reference & $\begin{array}{l}\text { Experimental } \\
\text { facility }\end{array}$ & $\begin{array}{l}\text { Dimensions of the } \\
\text { experimental facility }\end{array}$ & $\begin{array}{l}\text { Dynamic } \\
\text { and/or static }\end{array}$ & Research objective \\
\hline 1 & $\begin{array}{l}\text { Yoshida et al. } \\
\text { (2001) }\end{array}$ & $\begin{array}{l}\text { Full-scale } \\
\text { models of } \\
\text { walkway }\end{array}$ & $\begin{array}{l}6.0 \mathrm{~m}(\mathrm{~L}) \times 1.2 / 0.9 / 0.6 \mathrm{~m}(\mathrm{~W}) \\
3.0 \mathrm{~m}(\mathrm{~L}) \times 0.9 \mathrm{~m}(\mathrm{~W})\end{array}$ & $\begin{array}{l}\text { Dynamic } \\
\text { and static }\end{array}$ & $\begin{array}{l}\text { The walking speeds and flow coefficients in various static inclined } \\
\text { conditions, individuals' walking speeds on a dynamic inclined } \\
\text { platform. }\end{array}$ \\
\hline 2 & $\begin{array}{l}\text { Bles et al. } \\
(2002)\end{array}$ & $\begin{array}{l}\text { Ship motion } \\
\text { simulator }\end{array}$ & $4.0 \mathrm{~m}(\mathrm{~L}) \times 2.3 \mathrm{~m}(\mathrm{~W})$ & $\begin{array}{l}\text { Dynamic } \\
\text { and static }\end{array}$ & $\begin{array}{l}\text { The individual's walking speeds on corridors and staircases during } \\
\text { ship motion and listing. }\end{array}$ \\
\hline 3 & $\begin{array}{l}\text { Lee et al. } \\
(2004)\end{array}$ & $\begin{array}{l}\text { Ship corridor } \\
\text { simulator on a } \\
\text { training ship }\end{array}$ & $10.0 \mathrm{~m}(\mathrm{~L}) \times 1.20 \mathrm{~m}(\mathrm{~W})$ & $\begin{array}{l}\text { Dynamic } \\
\text { and static }\end{array}$ & $\begin{array}{l}\text { The walking speeds of s single person and a group of person on a } \\
\text { corridor with and without counter-flow, the effect of ship motion on } \\
\text { individuals' walking speeds. }\end{array}$ \\
\hline 4 & $\begin{array}{l}\text { Galea et al. } \\
(2012 ; 2004)\end{array}$ & SHEBA & $10.0 \mathrm{~m}(\mathrm{~L}) \times 2.0 \mathrm{~m}(\mathrm{~W})$ & Static & $\begin{array}{l}\text { The motion feature parameters of personnel in ship corridors and } \\
\text { staircases. }\end{array}$ \\
\hline 5 & $\begin{array}{l}\text { Zhang et al. } \\
(2017 ; 2016)\end{array}$ & $\begin{array}{l}\text { Marine rescue } \\
\text { simulator }\end{array}$ & $2.86 \mathrm{~m}(\mathrm{~L}) \times 1.29 \mathrm{~m}(\mathrm{~W})$ & Dynamic & $\begin{array}{l}\text { The data on adjustment actions, walking pauses, and the influence of } \\
\text { rolling angle on walking. }\end{array}$ \\
\hline 6 & $\begin{array}{l}\text { Sun et al. } \\
(2018 \mathrm{a} ; 2018 \mathrm{~b})\end{array}$ & $\begin{array}{l}\text { Ship corridor } \\
\text { simulator }\end{array}$ & $10.0 \mathrm{~m}(\mathrm{~L}) \times 1.8 \mathrm{~m}(\mathrm{~W})$ & Static & $\begin{array}{l}\text { The individuals' walking speeds on corridors of a ship with heeling, } \\
\text { trimming, and both. }\end{array}$ \\
\hline 7 & $\begin{array}{l}\text { Kwang et al. } \\
(2013)\end{array}$ & Passenger ship & $\begin{array}{l}10.0 \mathrm{~m}(\mathrm{~L}) \times 1.25 \mathrm{~m}(\mathrm{~W}) \\
35.0 \mathrm{~m}(\mathrm{~L}) \times 1.25 \mathrm{~m}(\mathrm{~W}) \\
4.98 \mathrm{~m}(\mathrm{~L}) \times 1.26 \mathrm{~m}(\mathrm{~W})\end{array}$ & $\begin{array}{l}\text { Dynamic } \\
\text { and static }\end{array}$ & $\begin{array}{l}\text { The individuals' walking speeds on corridors and staircases during } \\
\text { ship berthing and sailing conditions, the effect of ship motion on } \\
\text { individuals' walking speeds. }\end{array}$ \\
\hline 8 & $\begin{array}{l}\text { Walter et al. } \\
(2017 ; 2019)\end{array}$ & Research vessel & $8.9 \mathrm{~m}(\mathrm{~L}) \times 0.3 \mathrm{~m}(\mathrm{~W})$ & Dynamic & $\begin{array}{l}\text { The individual walking ability in different walking directions } \\
\text { (athwartship and fore-aft) and two ship motion conditions (i.e., roll }> \\
\text { pitch and pitch }>\text { roll). }\end{array}$ \\
\hline 9 & Na et al.(2019) & $\begin{array}{l}\text { Ro-Pax cruise } \\
\text { ship }\end{array}$ & $\begin{array}{l}20.35 \mathrm{~m}(\mathrm{~L}) \times 1.18 \mathrm{~m}(\mathrm{~W}) \\
10.0 \mathrm{~m}(\mathrm{~L}) \times 1.18 \mathrm{~m}(\mathrm{~W})\end{array}$ & $\begin{array}{l}\text { Dynamic } \\
\text { and static }\end{array}$ & $\begin{array}{l}\text { The individual's walking speed along the corridors and staircases, the } \\
\text { difference of individuals' walking speeds between ship sailing and }\end{array}$ \\
\hline
\end{tabular}




\begin{tabular}{|l|l|l|l|l|l|}
\hline & & & $4.98 \mathrm{~m}(\mathrm{~L}) \times 1.19 \mathrm{~m}(\mathrm{~W})$ & $\begin{array}{l}\text { berthing, the influence of gender and age on individuals' walking } \\
\text { speeds. }\end{array}$ \\
\hline 10 & $\begin{array}{l}\text { Wang et al. } \\
(2021 \mathrm{~b})\end{array}$ & Training ship & $10.0 \mathrm{~m}(\mathrm{~L}) \times 1.20 \mathrm{~m}(\mathrm{~W})$ & $\begin{array}{l}\text { Dynamic } \\
\text { and static }\end{array}$ & $\begin{array}{l}\text { Quantification of the effects of ship motion on an individual's walking } \\
\text { speed during training ship berthing and sailing conditions, the } \\
\text { difference between athwartship and fore-aft walking speeds, } \text { etc. }\end{array}$ \\
\hline 11 & This study & Training ship & $\begin{array}{l}10.0 \mathrm{~m}(\mathrm{~L}) \times 1.20 \mathrm{~m}(\mathrm{~W}) \\
5.4 \mathrm{~m}(\mathrm{~L}) \times 1.20 \mathrm{~m}(\mathrm{~W})\end{array}$ & $\begin{array}{l}\text { Dynamic } \\
\text { Quantification of the effects of ship motion on an individual's walking } \\
\text { speed on flat terrains and staircases during a training ship's different } \\
\text { sailing conditions (roll angular magnitudes), the difference of speeds } \\
\text { between athwartship and fore-aft walking, different decks, males and } \\
\text { females, etc. }\end{array}$ \\
\hline
\end{tabular}


The walking speeds in various static inclined

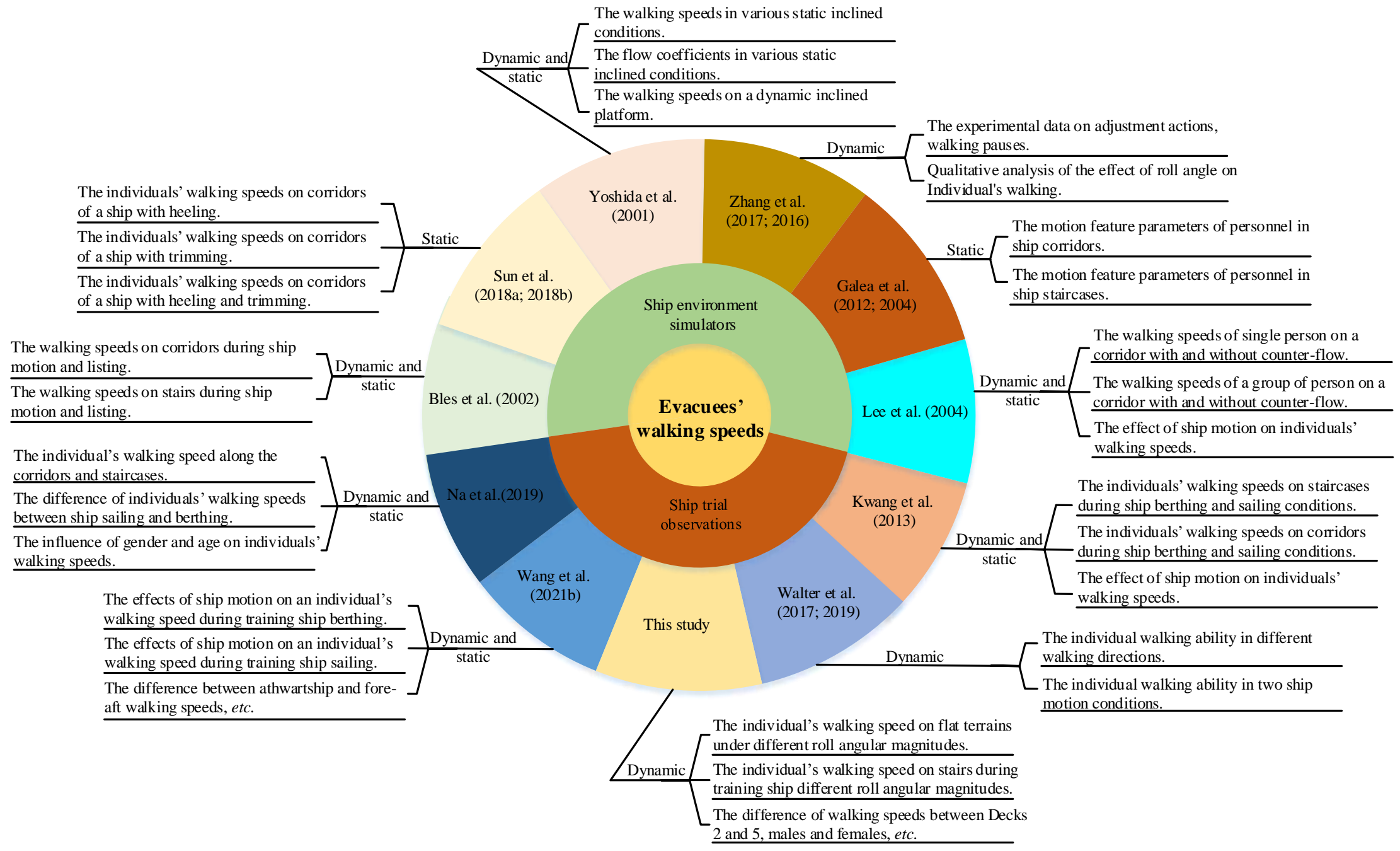

Fig. 2 The technology tree diagram of studies on individuals' walking speeds 


\section{Experimental data collection}

\subsection{Ship profile and experimental conditions}

In this study, the training ship "Yupeng" of DMU was utilized to carry out a series of human walking experiments. For their internship on the ship, 80 to 90 cadets were posted for 8 to 10 months every year from July to the following May. As shown in Table 1, many studies have used ship trial observation to investigate individuals' walking speeds in various ships, which have provided references for this study (Kwang-II, 2013; Lee et al., 2004; Na W.J. et al., 2019; Walter et al., 2017; 2019; Wang et al., 2021b). The ship is an ocean-going training vessel that sails to China, South Africa, Brazil and Argentina (Wang et al., 2021b). Table 2 summarises the specification of the ship. During the voyage, Yupeng often encounters various sea conditions and has different roll angular magnitudes, offering favourable conditions for carrying out the designed experiments. The ship is equipped with a ship motion attitude tester, and the ship's roll and pitch angles are displayed in real time in the Electronic Chart Display and Information System (ECDIS).

Table 2 Outline of the training ship "Yupeng"

\begin{tabular}{clcl}
\hline Category & \multicolumn{1}{c}{ Information } & Category & \multicolumn{1}{c}{ Information } \\
\hline Ship Name: & Yupeng & Type of Ship: & Training ship \\
Length overall: & $199.80 \mathrm{~m}$ & Moulded breadth: & $27.80 \mathrm{~m}$ \\
Deadweight: & $26,428.26 \mathrm{t}$ & Service speed: & $17.50 \mathrm{kn}$ \\
& 39 seafarers, 1 pilot, 6 & Navigation rout: & China $\leftrightarrow$ South America \\
Capacity: & South Africa \\
\hline
\end{tabular}

To study the effect of ship rolling on an individual's walking speed, the experimental participants should ideally carry out walking experiments with different magnitudes of roll motion. However, due to the uncontrollable motion states (angular roll magnitudes) of the ship, the human walking experiments can only be carried out in different sea areas and sea conditions on different days. Table 3 shows the weather, sea conditions and ship conditions during the experiments. During a particular voyage, there were 5 days (see Table 3 ) in which the sea conditions were suitable for the 
experiments because of the availability of participants, and the specific rolling magnitude of the ship. The data of individuals' walking speeds was collected and classified against the angular magnitudes of roll motion at $0^{\circ}, 1^{\circ}, 3^{\circ}, 5^{\circ}$ and $9^{\circ}$. As aforementioned, the ship's length is much larger than its width, its magnitude of pitch motion during navigation was less than $1^{\circ}$. Therefore, in this study we only considered the impact of the ship's rolling motion on an individual's walking speed. Since the ship motion in winds and waves is a very complicated process, the angular velocity or acceleration changes dynamically with time. During the experiments, only the angular magnitude of roll motion was measured, with angular velocity or angular acceleration not taken into account. However, the undamped motion equations (empirical formulae) of angular velocity of ship roll in waves are given in Table 3 based on the measured data of sea conditions and angular magnitudes of roll motion.

Table 3 Ship status and weather information during the experiments

\begin{tabular}{|c|c|c|c|c|}
\hline $\begin{array}{c}\text { Angular } \\
\text { magnitude of roll } \\
\text { motion }\left(\theta_{\mathrm{a}}\right)\end{array}$ & Category & Information & Category & Information \\
\hline \multirow[t]{5}{*}{ 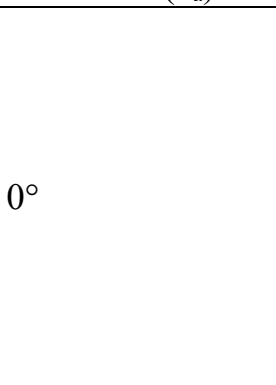 } & Time & $\begin{array}{l}\text { March 1, } \\
202014: 00\end{array}$ & Ship position & $\begin{array}{l}3^{\circ} 31^{\prime} 53^{\prime \prime S} \\
83^{\circ} 14^{\prime} 26^{\prime \prime} \mathrm{E}\end{array}$ \\
\hline & Vessel speed (kn) & $14.0 \mathrm{kn}$ & $\operatorname{Draft}(\mathrm{m})$ & $10.9 \mathrm{~m}$ \\
\hline & Course $\left(^{\circ}\right)$ & $\mathrm{C}=30.0^{\circ}$ & & \\
\hline & $\begin{array}{l}\text { Wave scale } \\
\text { (Beaufort) and } \\
\text { direction }\end{array}$ & $\mathrm{S}=3, \theta_{\mathrm{s}}=315^{\circ}$ & $\begin{array}{l}\text { Wind scale } \\
\text { (Beaufort) and } \\
\text { direction }\end{array}$ & $\begin{array}{l}\mathrm{W}=2, \\
\theta_{\mathrm{w}}=315^{\circ}\end{array}$ \\
\hline & $\begin{array}{l}\text { Angular magnitude } \\
\left.\text { of pitch motion ( }{ }^{\circ}\right)\end{array}$ & $\theta_{\mathrm{b}}=0^{\circ}$ & $\begin{array}{l}\text { Angular velocity of } \\
\text { roll motion }(\mathrm{rad} / \mathrm{s})\end{array}$ & $-2.5 \sin (2.5 t)$ \\
\hline \multirow{5}{*}{$1^{\circ}$} & Time & $\begin{array}{l}\text { October 8, } \\
201914: 00\end{array}$ & Ship position & $\begin{array}{l}21^{\circ} 55^{\prime} 42^{\prime} \mathrm{S} ; \\
033^{\circ} 01^{\prime} 06^{\prime \prime} \mathrm{W}\end{array}$ \\
\hline & Vessel speed (kn) & $14.2 \mathrm{kn}$ & Draft (m) & $10.2 \mathrm{~m}$ \\
\hline & Course $\left(^{\circ}\right)$ & $\mathrm{C}=107.6^{\circ}$ & & \\
\hline & $\begin{array}{l}\text { Wave scale } \\
\text { (Beaufort) and } \\
\text { direction }\end{array}$ & $\mathrm{S}=3, \theta_{\mathrm{s}}=45^{\circ}$ & $\begin{array}{l}\text { Wind scale } \\
\text { (Beaufort) and } \\
\text { direction }\end{array}$ & $\mathrm{W}=4, \theta_{\mathrm{w}}=45^{\circ}$ \\
\hline & $\begin{array}{l}\text { Angular magnitude } \\
\left.\text { of pitch motion ( }{ }^{\circ}\right)\end{array}$ & $\theta_{\mathrm{b}}=0.3^{\circ}$ & $\begin{array}{l}\text { Angular velocity of } \\
\text { roll motion }(\mathrm{rad} / \mathrm{s})\end{array}$ & $-2.1 \sin (2.1 t)$ \\
\hline \multirow{4}{*}{$3^{\circ}$} & Time & $\begin{array}{l}\text { October } 22, \\
201908: 00\end{array}$ & Ship position & $\begin{array}{l}25^{\circ} 32^{\prime} 48^{\prime \prime} \mathrm{S} \\
47^{\circ} 24^{\prime} 30^{\prime \prime} \mathrm{E}\end{array}$ \\
\hline & $\begin{array}{l}\text { Vessel speed }(\mathrm{kn}) \\
\text { Course }\left(^{\circ}\right)\end{array}$ & $\begin{array}{l}14.5 \mathrm{kn} \\
\mathrm{C}=064.3^{\circ}\end{array}$ & Draft (m) & $10.2 \mathrm{~m}$ \\
\hline & $\begin{array}{l}\text { Wave scale } \\
\text { (Beaufort) and } \\
\text { direction }\end{array}$ & $\mathrm{S}=3, \theta_{\mathrm{s}}=225^{\circ}$ & $\begin{array}{l}\text { Wind scale } \\
\text { (Beaufort) and } \\
\text { direction }\end{array}$ & $\begin{array}{l}\mathrm{W}=4, \\
\theta_{\mathrm{w}}=225^{\circ}\end{array}$ \\
\hline & $\begin{array}{l}\text { Angular magnitude } \\
\left.\text { of pitch motion ( }{ }^{\circ}\right)\end{array}$ & $\theta_{\mathrm{b}}=0.5^{\circ}$ & $\begin{array}{l}\text { Angular velocity of } \\
\text { roll motion }(\mathrm{rad} / \mathrm{s})\end{array}$ & $-1.6 \sin (1.6 t)$ \\
\hline
\end{tabular}




\begin{tabular}{|c|c|c|c|c|}
\hline \multirow{4}{*}{$5^{\circ}$} & Time & $\begin{array}{l}\text { January 13, } \\
202016: 00\end{array}$ & Ship position & $\begin{array}{l}32^{\circ} 39^{\prime} 36^{\prime \prime} \mathrm{S} \\
12^{\circ} 02^{\prime} 30^{\prime \prime} \mathrm{E}\end{array}$ \\
\hline & $\begin{array}{l}\text { Vessel speed (kn) } \\
\text { Course }\left(^{\circ}\right)\end{array}$ & $\begin{array}{l}13.3 \mathrm{kn} \\
\mathrm{C}=280.4^{\circ}\end{array}$ & Draft (m) & $8.5 \mathrm{~m}$ \\
\hline & $\begin{array}{l}\text { Wave scale } \\
\text { (Beaufort) and } \\
\text { direction }\end{array}$ & $\mathrm{S}=4, \theta_{\mathrm{s}}=270^{\circ}$ & $\begin{array}{l}\text { Wind scale } \\
\text { (Beaufort) and } \\
\text { direction }\end{array}$ & $\begin{array}{l}\mathrm{W}=6, \\
\theta_{\mathrm{w}}=270^{\circ}\end{array}$ \\
\hline & $\begin{array}{l}\text { Angular magnitude } \\
\text { of pitch motion }\left({ }^{\circ}\right)\end{array}$ & $\theta_{\mathrm{b}}=0.5^{\circ}$ & $\begin{array}{l}\text { Angular velocity of } \\
\text { roll motion }(\mathrm{rad} / \mathrm{s})\end{array}$ & $-0.8 \sin (0.8 t)$ \\
\hline \multirow{4}{*}{$9^{\circ}$} & Time & $\begin{array}{l}\text { October 19, } \\
201908: 00\end{array}$ & Ship position & $\begin{array}{l}32^{\circ} 37^{\prime} 54^{\prime \prime S} \\
030^{\circ} 44^{\prime} 6^{\prime \prime} \mathrm{E}\end{array}$ \\
\hline & $\begin{array}{l}\text { Vessel speed }(\mathrm{kn}) \\
\text { Course }\left(^{\circ}\right)\end{array}$ & $\begin{array}{l}13.5 \mathrm{kn} \\
\mathrm{C}=073.2^{\circ}\end{array}$ & Draft (m) & $10.2 \mathrm{~m}$ \\
\hline & $\begin{array}{l}\text { Wave scale } \\
\text { (Beaufort) and } \\
\text { direction }\end{array}$ & $\mathrm{S}=6, \theta_{\mathrm{s}}=135^{\circ}$ & $\begin{array}{l}\text { Wind scale } \\
\text { (Beaufort) and } \\
\text { direction }\end{array}$ & $\begin{array}{l}\mathrm{W}=8 \\
\theta_{\mathrm{w}}=135^{\circ}\end{array}$ \\
\hline & $\begin{array}{l}\text { Angular magnitude } \\
\text { of pitch motion }\left(^{\circ}\right)\end{array}$ & $\theta_{\mathrm{b}}=0.6^{\circ}$ & $\begin{array}{l}\text { Angular velocity of } \\
\text { roll motion }(\mathrm{rad} / \mathrm{s})\end{array}$ & $-0.6 \sin (0.6 t)$ \\
\hline
\end{tabular}

\subsection{Experimental design}

During the ship's voyage, since cadets and trainers carried out a series of training programmes on board, crew members perform their on-duty or daytime work. Therefore, to avoid disrupting the safe operation of the ship and the implementation of the training plan, 15 cadets and 2 crew members, including 13 males and 4 females, were randomly selected as the participants in this experiment, and completed all of the experimental tasks. Detailed information of the experimental participants is shown in Table 4. All participants were in a good physical condition and had no balance disorders, epilepsy or other health conditions.

Table 4 Basic information of the experimental participants

\begin{tabular}{cccccc|cccccc}
\hline No. & $\begin{array}{c}\text { Height } \\
(\mathrm{m})\end{array}$ & $\begin{array}{c}\text { Weight } \\
(\mathrm{kg})\end{array}$ & Age & Gender & Role & No. & $\begin{array}{c}\text { Height } \\
(\mathrm{m})\end{array}$ & $\begin{array}{c}\text { Weight } \\
(\mathrm{kg})\end{array}$ & Age & Gender & Role \\
\hline 1 & 1.68 & 55 & 20 & $\mathrm{~F}$ & Cadet & 10 & 1.73 & 65 & 24 & $\mathrm{M}$ & Cadet \\
2 & 1.65 & 58 & 21 & $\mathrm{~F}$ & Cadet & 11 & 1.72 & 74 & 22 & $\mathrm{M}$ & Cadet \\
3 & 1.65 & 65 & 20 & $\mathrm{~F}$ & Cadet & 12 & 1.75 & 64 & 21 & $\mathrm{M}$ & Cadet \\
4 & 1.70 & 65 & 21 & $\mathrm{M}$ & Cadet & 13 & 1.70 & 58 & 20 & $\mathrm{M}$ & Cadet \\
5 & 1.80 & 75 & 20 & $\mathrm{M}$ & Cadet & 14 & 1.85 & 96 & 20 & $\mathrm{M}$ & Cadet \\
6 & 1.72 & 80 & 21 & $\mathrm{M}$ & Cadet & 15 & 1.80 & 60 & 21 & $\mathrm{M}$ & Cadet \\
7 & 1.71 & 73 & 20 & $\mathrm{M}$ & Cadet & 16 & 1.76 & 70 & 55 & $\mathrm{M}$ & Steward \\
8 & 1.78 & 72 & 20 & $\mathrm{M}$ & Cadet & 17 & 1.60 & 64 & 53 & $\mathrm{~F}$ & Doctor \\
9 & 1.77 & 66 & 20 & $\mathrm{M}$ & Cadet & & & & & & \\
\hline
\end{tabular}

The experiments were carried out in the living area of the ship with the approval 
of DMU and the captain of "Yupeng". To increase the accuracy of the experimental results, the test area $(L)$ is larger than the calculation area $(S)$ to reduce the impact of the acceleration and deceleration process, and the width $(W)$ is the width of the corridor, as shown in Fig. 3. In the experiments, the speeds of normal walking and fast walking were tested. Normal walking refers to walking in a comfortable and natural way, and fast walking refers to walking as fast as possible but not running (Sun et al., 2018a; Wang et al., 2021b). To study the influence of the ship's rolling motion on an individual's walking speed on flat terrains, the athwartship corridor and fore-aft corridor in the living area were selected as experimental areas to test the normal and fast walking speed of the experimental participants in the athwartship corridor and to test the normal and fast walking speed in the fore-aft corridor. In the corridor experiments, $L$ is $12 \mathrm{~m}, S$ is $10 \mathrm{~m}$, and $W$ is $1.2 \mathrm{~m}$ while the dimensions of the test areas on the athwartship and fore-aft directions are the same. To study the impact of the ship's rolling amplitude (radian) on an individual's walking speed, the walking experiments were carried out on the second and fifth decks of the ship to obtain individuals' walking speeds, respectively, with the fifth deck 9 meters higher than the second deck.

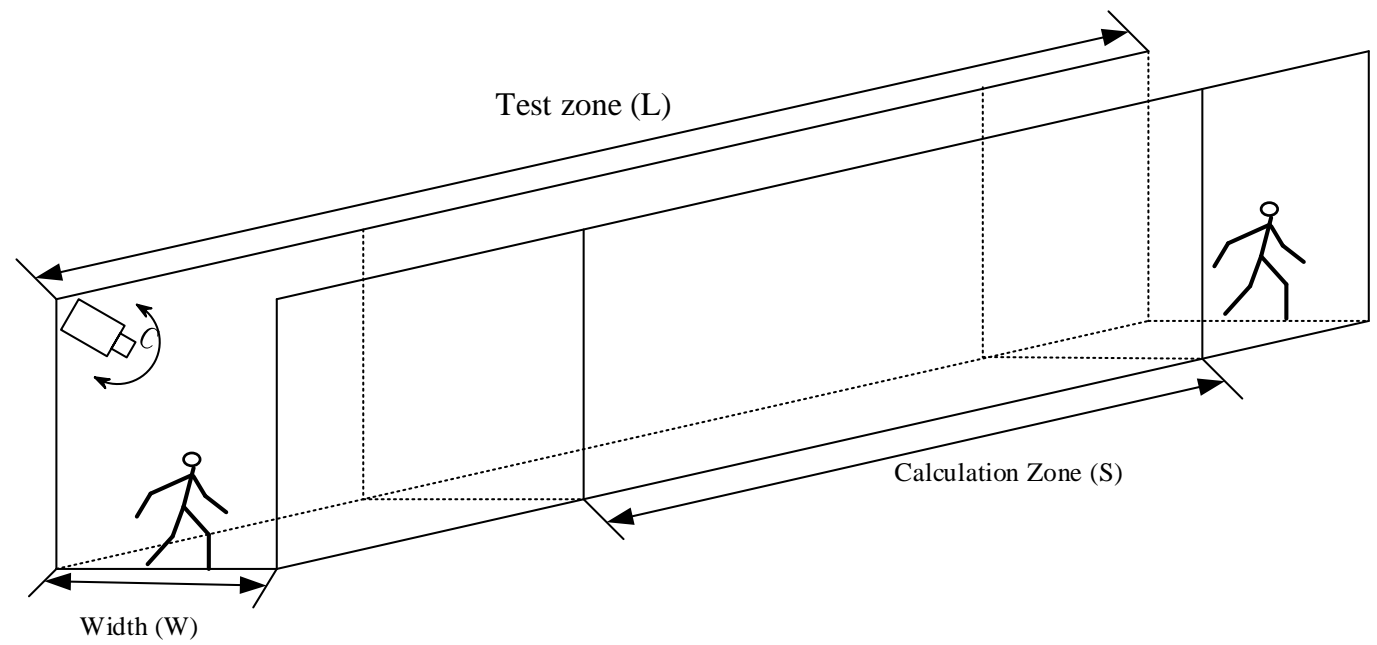

Fig. 3 Situation of the experimental area

To understand the impact of ship roll angular magnitude on the individuals' speeds of walking up the staircases and down the staircases, the stairway between the second and third decks of the living area was selected as the test area, and the experimental 
participants conducted the walking experiment at different roll angular magnitudes $\left(0^{\circ}\right.$, $5^{\circ}$ and $9^{\circ}$ ). The experiments on the staircase were similar to that on flat terrains, and the walking mode was divided into normal walking (up the staircases), normal walking (down the staircases), fast walking (up the staircases) and fast walking (down the staircases). In the experiments, $L$ is the walking distance of the personnel in the test area, $S$ is the slope length of the stair, and $W$ is the width of the stair. $L, S$ and $W$ are equal to $7.4 \mathrm{~m}, 5.4 \mathrm{~m}$ and $1.2 \mathrm{~m}$, respectively. To ensure the safety of personnel during the experiments and ensure that the experimental results are closer to the actual situation, the participants were allowed to use the handrail on the side of the staircase when and if necessary.

\subsection{Experimental procedure}

During the experiment, the experimental commander issued instructions, such as start walking, normal walking, fast walking, and stop walking. Once the participants received the instructions, they completed the required actions.

To obtain an individual's walking speed $v_{i}$, the time when the participant walked through the experimental area $S$ (as shown in Fig. 3) was measured and recorded by a camera in the experimental area. For example, in a certain experiment, an experimental participant enters the calculated area $S$ at time $t^{+}$and leaves at time $t^{-}$, where any part of the experimental participant's body is deemed to enter the calculated area when it crosses the boundary of the calculated area and is deemed to leave the calculated area when the body of the experimental participant completely leaves the calculated area. The time interval $\Delta t_{i}$ and walking speed $v_{i}$, of the participant that passes through the calculation area $S$ can be calculated by Eq. (1) and Eq. (2), and the average walking speed of $N$ participants can be calculated by Eq. (3).

$$
\begin{aligned}
\Delta t_{i} & =t_{i}^{\prime}-t_{i} \\
v_{i} & =S / \Delta t_{i}
\end{aligned}
$$




$$
\bar{v}=\frac{1}{N} \sum_{i=1}^{N} v_{i}
$$

\section{Results and discussion}

In the following part, the influence of different ship roll angular magnitudes on an individual's walking speed on flat terrains and staircases is analysed.

\subsection{Individuals' walking speeds on flat terrains}

The actual variation and change ratio of individuals' walking speeds on flat terrains, such as the overall distribution of individuals' walking speeds, the difference in individuals' speeds between athwartship and fore-aft walking, and between different decks, are analysed.

\subsubsection{Distribution of individuals' walking speeds on flat terrains}

To accurately describe the effect of the ship roll angular magnitude on an individual's walking speed, a large set of experimental data is analysed to obtain the distribution of individuals' walking speeds. Fig. 4 shows the individual walking speed distribution on the second deck against different ship roll angular magnitudes. Specifically, Fig. 4(a) shows individuals' normal walking speeds in the athwartship direction, Fig. 4(b) individuals' normal walking speeds in the fore-aft direction, Fig. 4(c) individuals' fast walking speeds in the athwartship direction, and Fig. 4(d) individuals' fast walking speeds in the fore-aft direction.

It is clear from Fig. 4(a) and Fig. 4(b) that in the normal walking mode, compared with the roll angular magnitude of $0^{\circ}$, when the roll angular magnitude was not $0^{\circ}$, the range of individuals' walking speeds is reduced. This finding is consistent with the research results of Wang et al. (2021b) and Kwang et al. (2013). It reveals that the periodic motion of the ship creates mental stress for the personnel, which affects their walking habits and makes them relatively cautious. As shown in Fig. 4(a)-(d), compared to the roll angular magnitude of $0^{\circ}$, the average walking speed was greatly reduced when the roll angular magnitude was $1^{\circ}$. However, the average walking speed did not decrease rapidly with an increasing roll angular magnitude. When the roll angular 
magnitude reaches $1^{\circ}, 3^{\circ}$ and $5^{\circ}$ respectively, the average walking speed did not substantially change, possibly due to the self-adjustment ability of the personnel to offset the impact of the ship roll at a small angular magnitude $\left(1^{\circ}\right.$ to $\left.5^{\circ}\right)$. However, when the angular magnitude exceeds $5^{\circ}$, the effect becomes abrupt. Compared with the angular magnitude of $5^{\circ}$, the average walking speed against an angular magnitude of $9^{\circ}$ showed a large decrease. In the case of a larger roll angular magnitude $\left(9^{\circ}\right)$, the balance of the personnel during walking was not sustained, and the self-adjustment ability was not enough to withstand the impact of the ship rolling. To maintain a balance, the personnel had to reduce their walking speed.
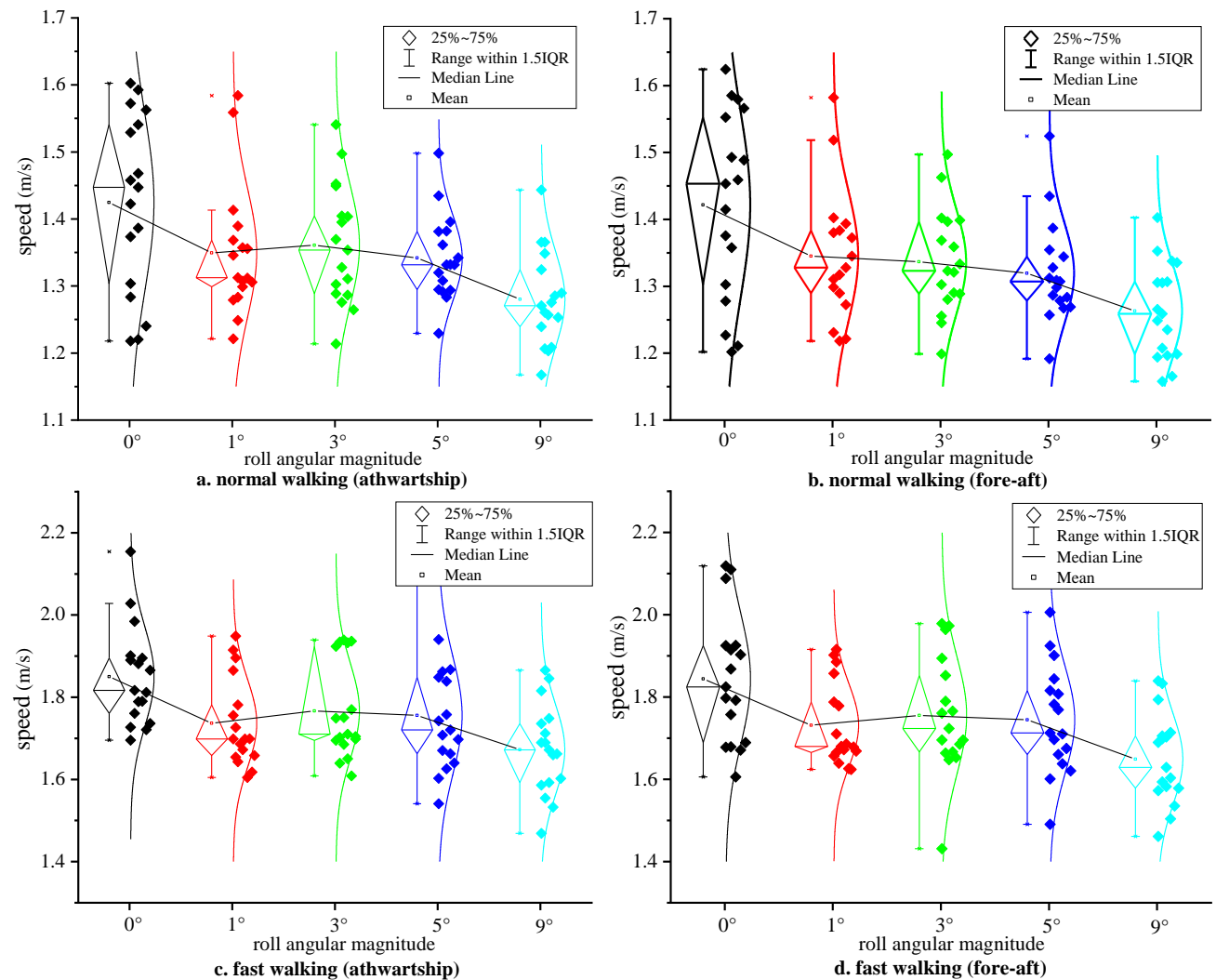

Fig. 4 Distribution of individuals' walking speeds on Deck 2 for different ship roll angular magnitudes

Table 5 shows the range and average value of individuals' walking speeds on the second deck against different roll angular magnitudes. When the angular magnitude of ship rolling was $1^{\circ}$, the normal walking speed (athwartship) ranged from $1.22 \mathrm{~m} / \mathrm{s}$ to $1.58 \mathrm{~m} / \mathrm{s}$, and the average speed was $1.35 \mathrm{~m} / \mathrm{s}$. The normal walking speed (fore-aft) was 
$1.21 \mathrm{~m} / \mathrm{s}$ to $1.58 \mathrm{~m} / \mathrm{s}$, and the average speed was $1.35 \mathrm{~m} / \mathrm{s}$. These results were similar to the average walking speed obtained by $\mathrm{Na}$ et al. (2019) in a ship sailing experiment (ship roll angular magnitude was $1^{\circ}$ ) and similar to the results (i.e., $1.47 \mathrm{~m} / \mathrm{s}$ ) obtained by Kwang et al. (2013) in a ship sailing experiment (ship roll angular magnitude was $\left.1^{\circ}\right)$. This helps verify the reliability of our experimental results.

According to the comparison and analysis of the contents in Fig. 4 and Table 5, due to the differences in human physical characteristics, obvious differences in individuals' walking speeds were observed. However, the variation trend of an individual's average walking speed was similar, that is, with an increase in the roll angular magnitude, the individuals' average walking speeds presented a downward trend. For example, the results between the pair of $1^{\circ}$ and $0^{\circ}$ and the pair of $9^{\circ}$ and $5^{\circ}$ showed a very clear downward trend. In terms of normal walking (athwartship), using the experimental results (i.e., $1.53 \mathrm{~m} / \mathrm{s}$ average walking speed) of Wang et al. (2021b) during the berthing period of the ship as a baseline, the average walking speed against the ship roll angular magnitudes at $0^{\circ}, 1^{\circ}, 3^{\circ}, 5^{\circ}$ and $9^{\circ}$ decreased by $7 \%, 12 \%, 11 \%$, $12 \%$ and $16 \%$, respectively. It indicates that ship motion causes a decrease in individuals' walking speeds of $7 \%$ to $16 \%$. These results are similar to the ones by $\mathrm{Na}$ et al. (2019), in which the ship motion reduced an individual's walking speed by $13.5 \%$. They are also similar to those by Bles et al. (2002), in which the cyclical motion of ships decreased an individual's walking speed by as much as $15 \%$. However, the value of an individual's walking speed was not as large as the results of Kwang et al. (2013), in which the ship motion caused an individual's walking speed to decrease by $27.2 \%$. It is, however, noted that the participants in the experiment by Kwang et al. were unfamiliar with the environment of the ship and have the physical difference compared to the experiment in this research.

Table 5 Speed ranges and mean speeds for different ship roll angular magnitudes

$\begin{array}{lll}\text { Experimental results } & \text { Ship roll } & \\ \text { category } & \text { angular } & \text { Speed range }(\mathrm{m} / \mathrm{s})\end{array} \quad$ Mean speed $(\mathrm{m} / \mathrm{s})$




\begin{tabular}{llll}
\hline Normal walking speed & $0^{\circ}$ & $1.22-1.60$ & 1.43 \\
(athwartship) & $1^{\circ}$ & $1.22-1.58$ & 1.35 \\
& $3^{\circ}$ & $1.21-1.54$ & 1.36 \\
& $5^{\circ}$ & $1.23-1.50$ & 1.34 \\
Normal walking speed & $9^{\circ}$ & $1.20-1.43$ & 1.29 \\
(fore-aft) & $0^{\circ}$ & $1.20-1.62$ & 1.42 \\
& $1^{\circ}$ & $1.21-1.58$ & 1.35 \\
& $3^{\circ}$ & $1.20-1.50$ & 1.34 \\
Fast walking speed & $5^{\circ}$ & $1.19-1.52$ & 1.32 \\
(athwartship) & $9^{\circ}$ & $1.18-1.41$ & 1.28 \\
& $0^{\circ}$ & $1.69-2.16$ & 1.84 \\
& $1^{\circ}$ & $1.61-1.95$ & 1.74 \\
& $3^{\circ}$ & $1.61-1.94$ & 1.77 \\
\hline Fast walking speed & $5^{\circ}$ & $1.54-2.12$ & 1.76 \\
(fore-aft) & $9^{\circ}$ & $1.49-1.89$ & 1.68 \\
\hline $0^{\circ}$ & $1.61-2.12$ & 1.85 \\
& $1^{\circ}$ & $1.62-1.92$ & 1.73 \\
& $3^{\circ}$ & $1.43-1.98$ & 1.76 \\
& $5^{\circ}$ & $1.49-2.01$ & 1.74 \\
& $9^{\circ}$ & $1.45-1.89$ & 1.67 \\
\hline
\end{tabular}

\subsubsection{Comparative analysis of walking speeds in athwartship and fore-aft}

When a ship is stationary, humans walk the same way in all directions. When it is in motion, the periodic motion of the deck causes a change in the gait of the human on board, which varies with the change in direction (Haaland et al., 2015; Wang et al., 2021b). As a result of this rolling motion, humans are affected differently when they walk along the athwartship and fore-aft axes of a ship (Walter et al., 2017; Walter et al., 2019). Therefore, the analysis of the athwartship walking speed and fore-aft walking speed will prospectively reflect the impact of ship motion on the actual walking ability in these two directions.

Fig. 5(a) and Fig. 5(b) show the variation trend of the average walking speed (athwartship/fore-aft) on the second and fifth decks, respectively. The analysis shows that when the roll angular magnitude was $0^{\circ}$, the average walking speeds in athwartship and fore-aft directions were similar. With an increase in the ship roll angular magnitude, the variation trends of the average walking speeds on the two decks were similar. In the 
same direction, the speed of fast walking is greater than that of normal walking, as shown in Fig. 5(a). Consider the average speed of athwartship walking on the second deck as an example. The speed of normal walking was $76.3 \%$ to $77.5 \%$ of that of fast walking, which was similar to the research results of Sun et al $(2018 ; 2018 \mathrm{a})$ and Wang et al. (2021b). In the same walking mode, the speed of athwartship walking is slightly higher than that of fore-aft walking. As shown in Fig. 5(b), taking the average speed of fast walking on the fifth deck as an example, the speed of athwartship walking was 1.00 to 1.02 times higher than that of fore-aft walking. It is consistent with the findings from (Haaland et al., 2015; Walter et al., 2017; Walter et al., 2019) and indicates that the influence of ship rolling on fore-aft walking is greater than that on athwartship walking when the ship rolling motion is greater than the pitching one.
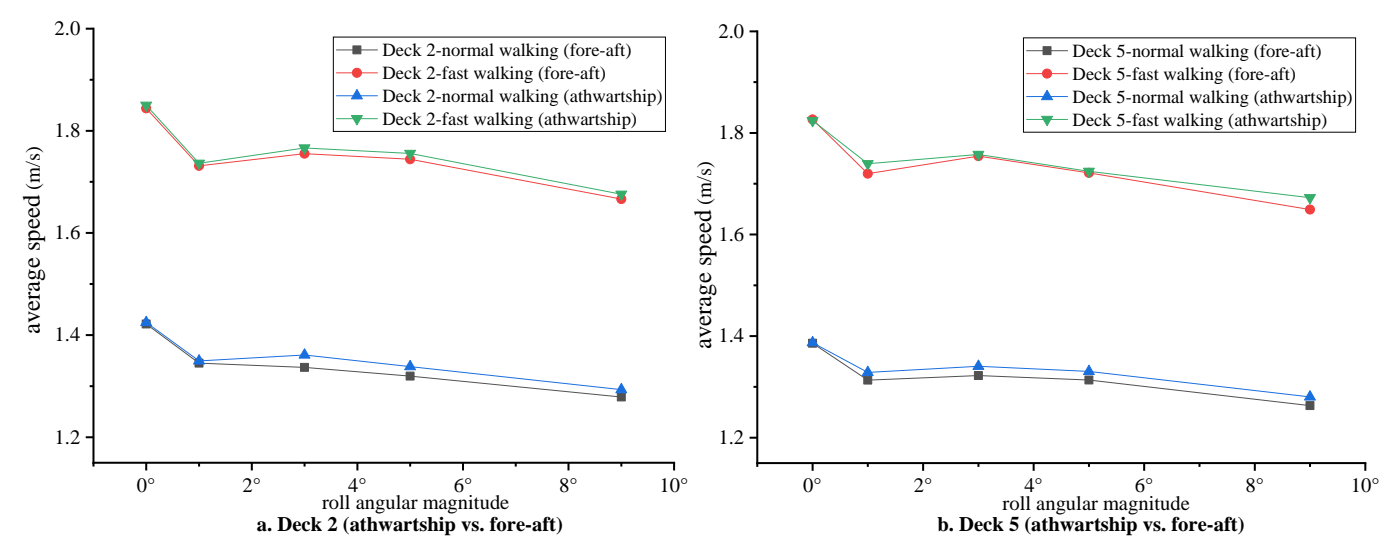

Fig. 5 Comparison of individuals' average walking speeds in athwartship/fore-aft directions

To understand whether the differences in individuals' walking speeds in different walking directions have statistically significant characteristics, a one-way ANOVA of the result on the second deck, as an illustrative example was applied to compare and analyse the speed difference between athwartship walking and fore-aft walking. The results are shown in Table 6 . At the 95\% confidence level, except when the roll angular magnitude was $9^{\circ}$, in the fast walking mode, the difference between athwartship and fore-aft walking speeds of the two directions of the other groups are not statistically significant. 
Table 6 ANOVA analysis results of walking speeds athwartship and aft-fore at different ship roll angular magnitudes

\begin{tabular}{lllll}
\hline $\begin{array}{l}\text { Ship roll angular } \\
\text { magnitude }\end{array}$ & Walking pattern & Mean & Mean difference & $\mathrm{p}$ \\
\hline $0^{\circ}$ & Normal walking & -0.0030 & 0.0123 & 0.809 \\
& Fast walking & -0.0060 & 0.0327 & 0.856 \\
\hline \multirow{2}{*}{$1^{\circ}$} & Normal walking & -0.0045 & 0.0054 & 0.424 \\
& Fast walking & -0.0051 & 0.0072 & 0.489 \\
\hline \multirow{2}{*}{$3^{\circ}$} & Normal walking & -0.0242 & 0.0149 & 0.123 \\
& Fast walking & -0.0112 & 0.0138 & 0.430 \\
$5^{\circ}$ & Normal walking & -0.0222 & 0.0120 & 0.082 \\
& Fast walking & -0.0113 & 0.0108 & 0.311 \\
\hline \multirow{2}{*}{$9^{\circ}$} & Normal walking & -0.0144 & 0.0091 & 0.133 \\
& Fast walking & -0.0095 & 0.0043 & 0.041 \\
\hline
\end{tabular}

\subsubsection{Comparative analysis of walking speeds on Decks 2 and 5}

Due to the influence of ship roll, for the same roll angular magnitude, the higher the deck, the greater the amplitude (radian) of the ship roll is. This will cause more personnel to be affected by the ship motion (Bles, 2002; Wang et al., 2021b). Fig. 6 shows a comparison of the average walking speeds on the second and fifth decks in normal and fast walking modes at different roll angular magnitudes. Fig. 6(a) shows the variation in the average athwartship/fore-aft walking speed for the normal walking mode. Fig. 6(b) shows the variation in the average athwartship/fore-aft walking speed in the fast walking mode. As shown in Fig. 6(a), in the normal walking mode, the average athwartship walking speed at the second deck was greater than that at the fifth deck, and the average fore-aft walking speed at the second deck was also greater than that at the fifth deck. It is consistent with the finding from (Wang et al., 2021b), indicating that the ship rolling amplitude of the fifth deck is greater than that of the second deck, and its influence on individuals' walking speeds on the fifth deck is also greater than that on the second deck. As shown in Fig. 6(b), in the fast walking mode, the average walking speed of individuals on the second and fifth decks was similar to that in the normal walking mode. 

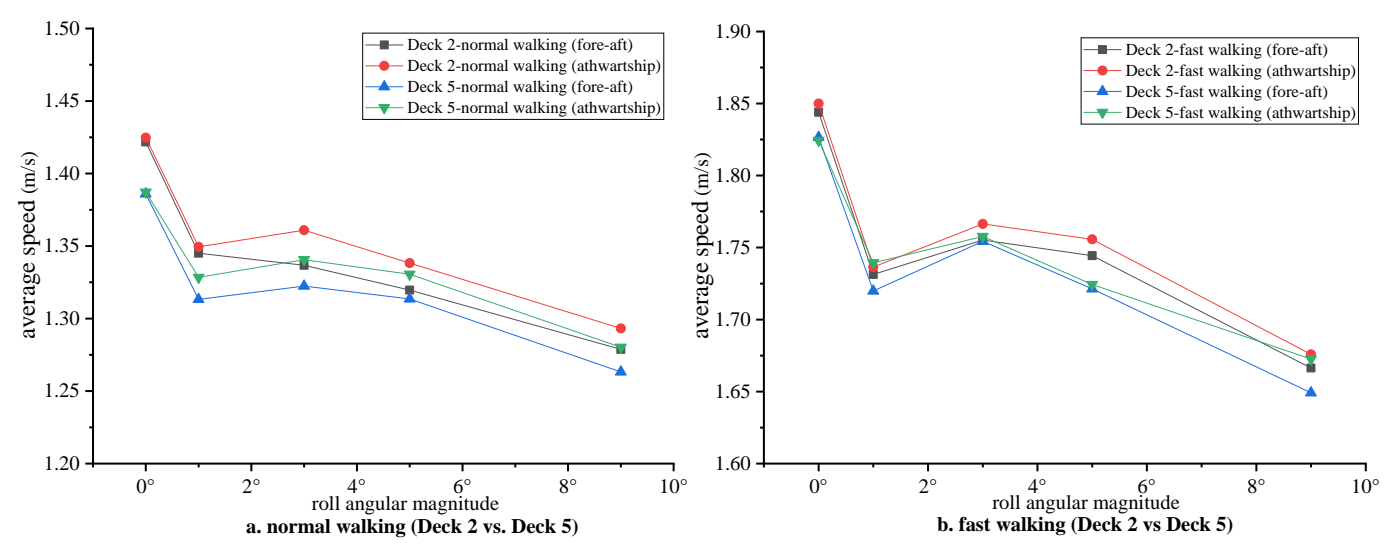

Fig. 6 Comparison of individuals' average walking speeds on the second and fifth decks

To analyse whether the difference in individuals' walking speeds between the second and the fifth decks with regards to the two walking modes was statistically significant, a one-way ANOVA of the normal walking (athwartship/fore-aft), as an illustrative example, was conducted to analyse the difference. The results are shown in Table 7. As shown in Table 7, at the 95\% confidence level, except for the roll angular magnitude of $1^{\circ}$, in the fore-aft walking mode, the difference in walking speed between the second and fifth decks was statistically significant. The walking speeds in the two directions of the other groups were not statistically significant.

Table 7 ANOVA analysis results for walking speeds on Deck 2 and Deck 5 at different roll angular magnitudes

\begin{tabular}{lllll}
\hline $\begin{array}{l}\text { Ship roll angular } \\
\text { magnitude }\end{array}$ & Walking direction & Mean & Mean difference & $\mathrm{p}$ \\
\hline $0^{\circ}$ & Aft-fore & 0.0358 & 0.0184 & 0.070 \\
& Athwartship & 0.0377 & 0.0220 & 0.106 \\
\hline $1^{\circ}$ & Aft-fore & 0.0318 & 0.0099 & 0.005 \\
& Athwartship & 0.0211 & 0.0148 & 0.174 \\
\hline $3^{\circ}$ & Aft-fore & 0.0143 & 0.0096 & 0.155 \\
& Athwartship & 0.0204 & 0.0148 & 0.187 \\
\hline $5^{\circ}$ & Aft-fore & 0.0060 & 0.0078 & 0.452 \\
& Athwartship & 0.0012 & 0.0095 & 0.899 \\
\hline $9^{\circ}$ & Aft-fore & 0.0156 & 0.0110 & 0.175 \\
& Athwartship & 0.0129 & 0.0097 & 0.203 \\
\hline
\end{tabular}




\subsubsection{Comparative analysis of walking speeds of males and females}

Gender is another important factor that affects individuals' walking speeds (Sun et al., 2018a; Sun et al., 2018b). To analyse the influence of the gender factor on an individual's walking speed, the experimental participants were divided into two groups according to their gender, and the changes in the average speed (second deck) of males, females and the whole group were compared and analysed, as shown in Fig. 7. Fig. 7(ad) shows a comparison of the average speeds of individuals' normal walking (athwartship), normal walking (fore-aft), fast walking (athwartship) and fast walking (fore-aft) at different roll angular magnitudes.

It can be seen from Fig. 7 that for the same walking mode, the average walking speeds of males and females present a similar trend. As shown in Fig. 7(a), in the normal walking mode, with an increase in the roll angular magnitude, the average walking speed (athwartship) of males decreased from $1.45 \mathrm{~m} / \mathrm{s}$ to $1.30 \mathrm{~m} / \mathrm{s}$, while that of females decreased from $1.35 \mathrm{~m} / \mathrm{s}$ to $1.29 \mathrm{~m} / \mathrm{s}$. In the case of the same roll angular magnitude, the average walking speed of males was higher than that of females, which was consistent with the research results by Sun et al. (2018a) and may be related to the difference in the physical quality between males and females. It can be seen from Fig. 7(a-b) that, in the normal walking mode, as the roll angular magnitude increased, the speed difference between males and females decreased, which was similar to the research results by $\mathrm{Na}$ et al. (2019). In the fast walking mode, as shown in Fig. 7(c-d), with an increase in the roll angular magnitude, the speed difference between males and females increased. This finding indicates that for different walking modes, with an increase in the roll angular magnitude, the difference in the walking ability between males and females also differed. 

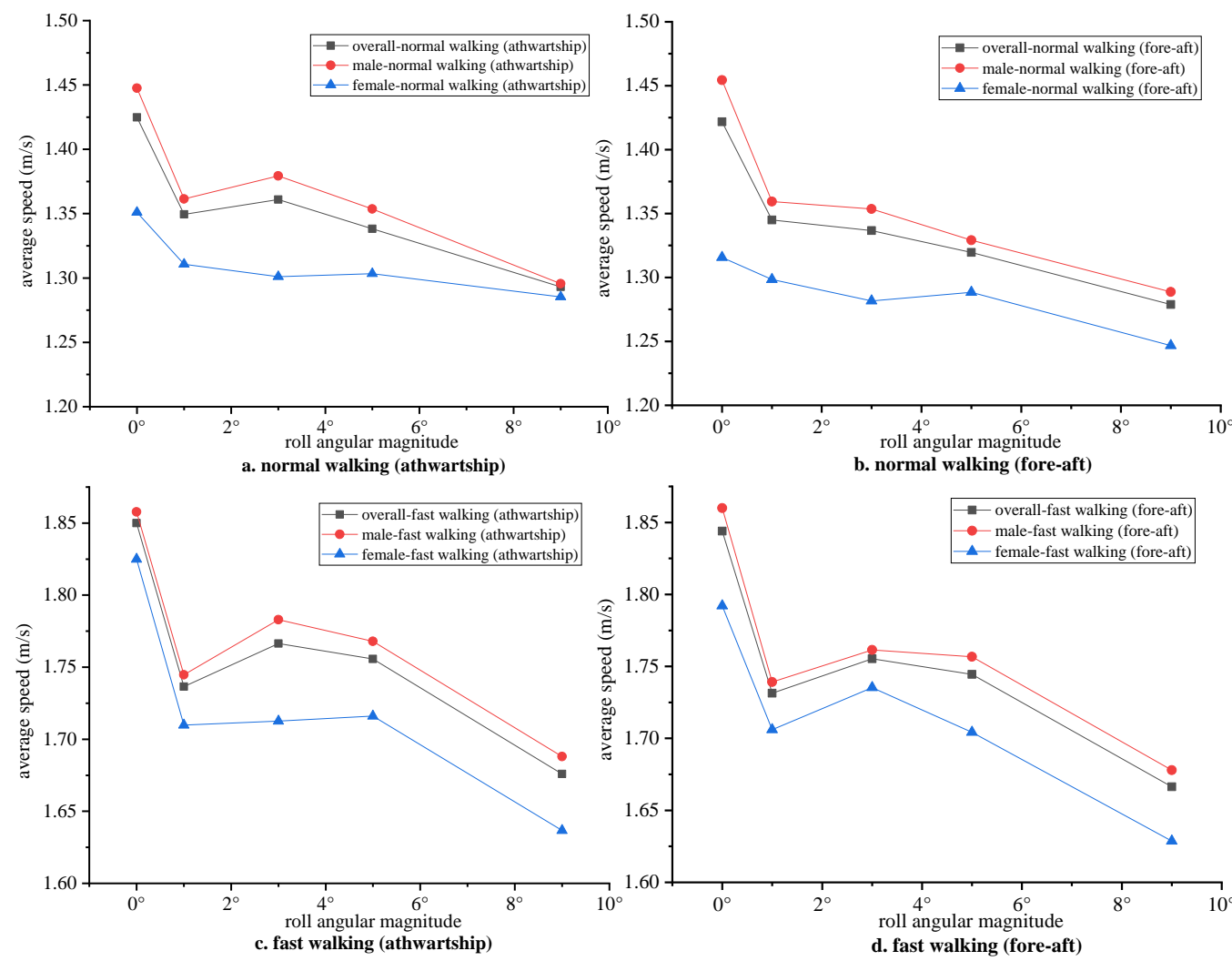

Fig. 7 Comparison of individuals' average walking speeds of males and females

To analyse whether the walking speeds of males and females were statistically significant, a one-way ANOVA of normal walking (fore-aft) speed as an illustrative example, was applied to analyse the differences. As shown in Table 8, at the $95 \%$ confidence level, the difference in walking speed between males and females was not statistically significant.

Table 8 ANOVA analysis result of normal walking speeds (aft-fore) of males and females at different roll angular magnitudes

\begin{tabular}{llll}
\hline Ship roll angular magnitude & Mean & Mean difference & $\mathrm{p}$ \\
\hline $0^{\circ}$ & 0.164 & 0.113 & 0.242 \\
$1^{\circ}$ & 0.024 & 0.050 & 0.666 \\
$3^{\circ}$ & 0.042 & 0.044 & 0.414 \\
$5^{\circ}$ & 0.007 & 0.022 & 0.764 \\
$9^{\circ}$ & 0.032 & 0.031 & 0.382 \\
\hline
\end{tabular}




\subsubsection{Comparative analysis of walking speed reduction ratio}

To analyse the reduction ratio of individuals' walking speeds against different roll angular magnitudes, the variation ratio of individuals' walking speeds at different roll angular magnitudes against that at $0^{\circ}$ was calculated. Fig. 8(a) shows the distribution of walking speed reduction ratios for the modes of normal and fast walking on the second deck. It can be seen from the analysis results that the walking speed reduction ratios of individuals decrease with increased roll angular magnitudes. In the normal walking mode, the speed reduction ratio of athwartship walking was greater than that of fore-aft walking, and the same results were obtained in terms of the fast walking mode. When the roll angular magnitude was $3^{\circ}$, an individual's walking speed reduction ratio was the largest at $95 \%$; when the roll angular magnitude was $9^{\circ}$, an individual's walking speed reduction ratio was the smallest at $90 \%$. This finding was similar to the research results by Yoshida et al. (2001), where the reduction ratio of an individual's walking speed was $80 \%$ to $86 \%$ when the ship roll angular magnitude was $10^{\circ}$.

To analyse the impact of ship dynamic motion and static heeling on an individual's walking speed, the results obtained in this study were compared with relevant studies (Bles, 2002; Meyer-König et al., 2007; Sun et al., 2018a). Fig. 8(b) shows the distribution of individual walking speed reduction ratios for the state of static heeling. The comparative analysis showed that for ship roll angular magnitudes of $1^{\circ}, 3^{\circ}$ and $5^{\circ}$, the speed reduction ratio caused by ship motion (rolling) was equal to that caused by static heeling of $10^{\circ}$ to $15^{\circ}$. When the ship rolls at an angular magnitude of $9^{\circ}$, the speed reduction ratio caused by the ship's motion (roll) was equal to that caused by static heeling of $15^{\circ}$ to $20^{\circ}$. Compared with static heeling, ship rolling had a greater impact on an individual's walking speed (Wang et al., 2021b). 

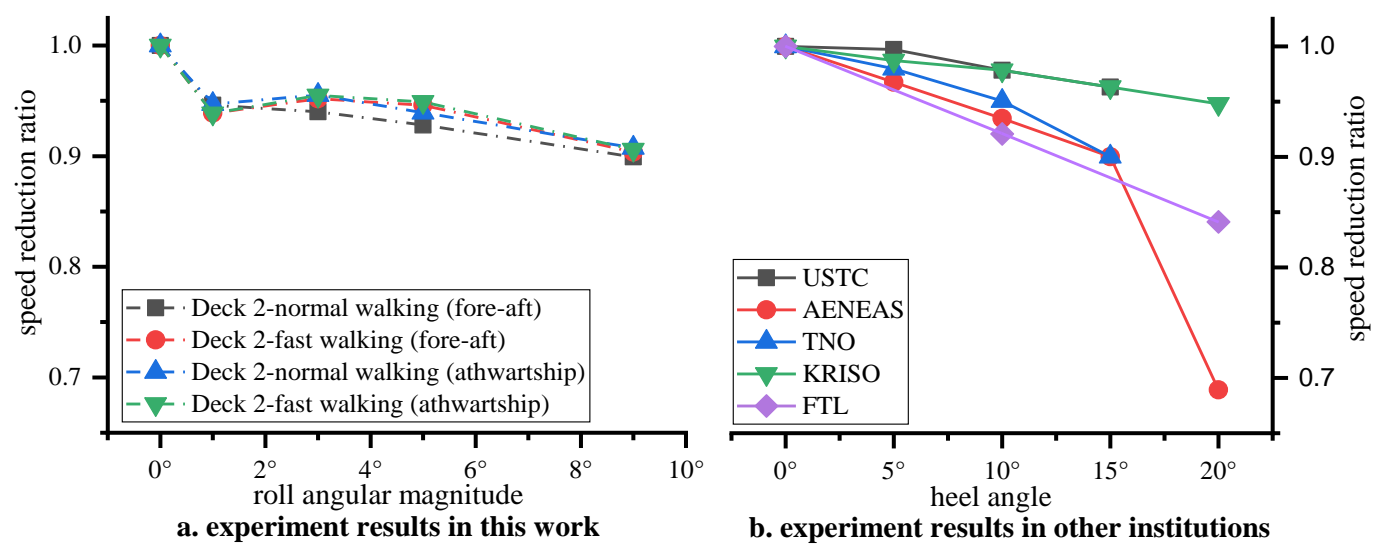

b. experiment results in other institutions

Fig. 8 Reduction ratio of average individuals' walking speeds on second deck compared with static (heeling)

\subsection{Individuals' walking speeds on staircases}

In the following section, the actual variations and change ratios in individuals' walking speeds on a staircase, the difference in individuals' speeds of walking up and down the staircases, and between males and females on the staircases are discussed.

\subsubsection{Distribution of individuals' walking speeds on staircases}

Fig. 9 shows the distribution of individuals' walking speeds on the staircases with different ship roll angular magnitudes. Fig. 9(a) shows individuals' walking speeds travelling up the staircases (normal walking), Fig. 9(b) individuals' walking speeds travelling down the staircases (normal walking), Fig. 9(c) individuals' walking speeds travelling up the staircases (fast walking), and Fig. 9(d) individuals' walking speeds travelling down the staircases (fast walking).

It can be seen from Fig. 9(a) and Fig. 9(b) that, in the normal walking mode, when the roll angular magnitude is $0^{\circ}$, the speed range of individuals' walking up the staircases was $0.53 \mathrm{~m} / \mathrm{s}$ to $0.72 \mathrm{~m} / \mathrm{s}$ and the average speed was $0.61 \mathrm{~m} / \mathrm{s}$ while the speed range of walking down the staircases was $0.63 \mathrm{~m} / \mathrm{s}$ to $0.90 \mathrm{~m} / \mathrm{s}$ and the average speed was $0.73 \mathrm{~m} / \mathrm{s}$. For an individual's average walking speed, the values obtained in this study were similar to those obtained by $\mathrm{Na}$ et al. (2019), in which the individuals' average speeds of walking up the staircases and down the staircases were $0.57 \mathrm{~m} / \mathrm{s}$ and $0.71 \mathrm{~m} / \mathrm{s}$, respectively. However, these results were different from the ones by Kwang 
et al. (2013), in which an individual's average speed of walking up the staircases was $0.71 \mathrm{~m} / \mathrm{s}$ and the average speed of walking down the staircases was $0.75 \mathrm{~m} / \mathrm{s}$. Compared with the roll angular magnitude of $0^{\circ}$, when the roll angular magnitude was changed to $5^{\circ}$ and $9^{\circ}$, the individuals' average walking speeds decreased (e.g., by approximately $5 \%$ for the walking up the staircases case when rolling angular magnitude was $9^{\circ}$ ). This result indicated that a ship's rolling motion had a smaller effect on staircase walking than flat walking, which was consistent with the results by Na et al. (2019).

It can be seen from Fig. 9 (c) and Fig. 9 (d) that, in the fast walking mode, when the roll angular magnitude was $0^{\circ}$, an individuals' walking speed when travelling up the staircases ranged from $0.80 \mathrm{~m} / \mathrm{s}$ to $1.68 \mathrm{~m} / \mathrm{s}$ with an average speed of $1.27 \mathrm{~m} / \mathrm{s}$, and the speed of walking down the staircases varied from $0.95 \mathrm{~m} / \mathrm{s}$ to $1.66 \mathrm{~m} / \mathrm{s}$ with an average speed of $1.24 \mathrm{~m} / \mathrm{s}$. Similar to the normal walking mode, when the roll angular magnitude was increased to $5^{\circ}$ and $9^{\circ}$, the individuals' average walking speeds also decreased. For example, when roll angular magnitude was $9^{\circ}$, an individual's average speed of walking down the staircases decreased by approximately $15.2 \%$, which indicated that the effect of ship motion on an individual's fast walking was greater than that of normal walking. 

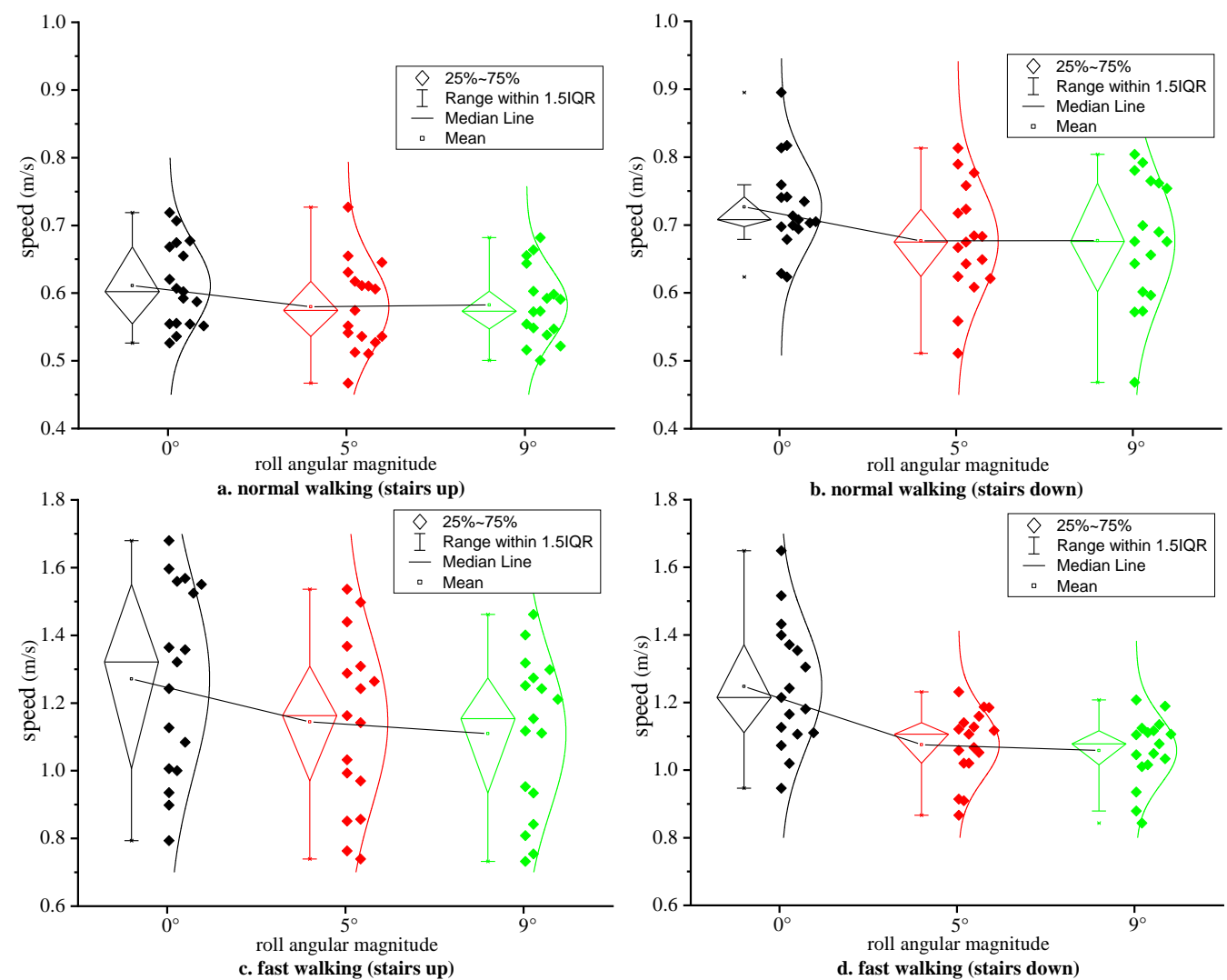

Fig. 9 Distribution of individuals' walking speeds on staircases with different ship roll angular magnitudes

\subsubsection{Comparative analysis of speeds of walking up and down the staircases}

Fig. 10 shows the comparison of individuals' average speeds of walking up and down the staircases. In the normal walking mode, when the roll angular magnitude was $0^{\circ}$, an individual's average speed of walking up the staircases was $0.61 \mathrm{~m} / \mathrm{s}$, and the average speed of walking down the staircases was $0.73 \mathrm{~m} / \mathrm{s}$. The average speed of walking down the staircases was approximately $19.7 \%$ faster than that up the staircases, which was similar to the results obtained by $\mathrm{Na}$ et al. (2019). When the roll angular magnitude was $5^{\circ}$ and $9^{\circ}$, the individuals' average walking speeds did not change substantially, which may be due to the notion that individuals used handrails when the ship was rolling at a large amplitude. When the roll angular magnitude was $9^{\circ}$, the average speed of walking down the staircases was $14.7 \%$ faster than that of walking up the staircases. 
In the fast walking mode, when the roll angular magnitude was $0^{\circ}$, the individuals' average speeds of walking up the staircases and down the staircases were $1.27 \mathrm{~m} / \mathrm{s}$ and $1.24 \mathrm{~m} / \mathrm{s}$, respectively. Unlike the normal walking, the average speed of walking down the staircases was not faster than that of walking up the staircases, possibly as it was easier for individuals to maintain their balance while walking up the staircases in the fast walking mode (Lee et al., 2004) and a handrail is more helpful to people in the process of walking up the staircases, especially for elder persons, who are more likely to use a handrail (Na W.J. et al., 2019). Similarly, individuals' average walking speed did not change substantially when the roll angular magnitude was $5^{\circ}$ and $9^{\circ}$.

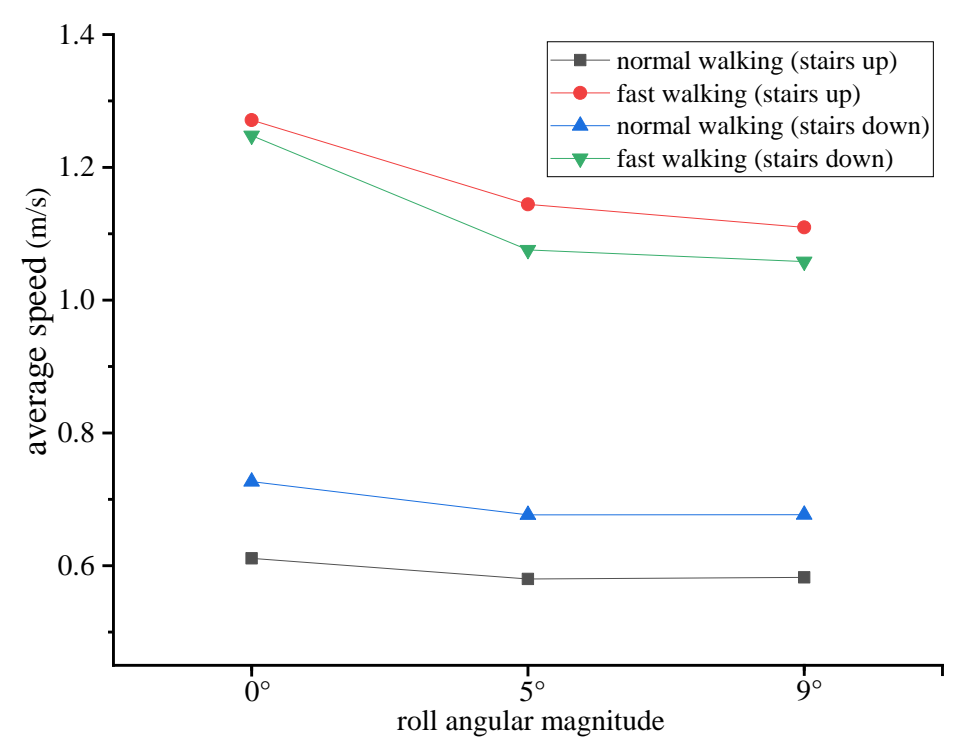

Fig. 10 Comparison of individuals' average walking speeds for walking the up and down the staircases

\subsubsection{Comparative analysis of walking speeds of males and females}

To understand the influence of gender on the speeds of walking up and down the staircases, the average walking speeds of males, females and the whole group for different walking modes were compared and analysed, as shown in Fig. 11. Fig. 11(a) shows an individual's average speed of walking up the staircases (normal walking), Fig. 11(b) an individual's average speed of walking down the staircases (normal walking), Fig. 11(c) an individual's average speed of walking up the staircases (fast walking), and 
Fig. 11(d) an individual's average speed of walking down the staircases (fast walking).

It can be seen from Fig. 11(a) and Fig. 11(b) that, in the normal walking mode, when the roll angular magnitude was $0^{\circ}$, the average speed of walking up the staircases for males and females was $0.62 \mathrm{~m} / \mathrm{s}$ and $0.58 \mathrm{~m} / \mathrm{s}$ respectively, while males were $6.9 \%$ faster than females. The average speed of walking down the staircases was $0.73 \mathrm{~m} / \mathrm{s}$ and $0.71 \mathrm{~m} / \mathrm{s}$ for males and females respectively, while males were $2.8 \%$ faster than females. When the roll angular magnitude was $5^{\circ}$ and $9^{\circ}$, individuals' average walking speeds for males and females showed an insignificant change. When the roll angular magnitude was $9^{\circ}$, individuals' average speeds of walking up the staircases were 0.59 $\mathrm{m} / \mathrm{s}$ and $0.56 \mathrm{~m} / \mathrm{s}$ for males and females, respectively. It means that males were $5.4 \%$ faster than females. Individuals' average speeds of walking up the staircases were 0.69 $\mathrm{m} / \mathrm{s}$ and $0.65 \mathrm{~m} / \mathrm{s}$ for males and females, respectively, which means that males were $6.2 \%$ faster than females. These results are similar to the ones by Kwang et al. (2013).

It can be seen from Fig. 11(c) and Fig. 11(d) that, in the fast walking mode, when the roll angular magnitude was $0^{\circ}$, the average speed of walking up the staircases was $1.38 \mathrm{~m} / \mathrm{s}$ and $0.91 \mathrm{~m} / \mathrm{s}$ for males and females, respectively while males were $51.6 \%$ faster than females. The average speed of walking down the staircases was $1.31 \mathrm{~m} / \mathrm{s}$ and $1.04 \mathrm{~m} / \mathrm{s}$ for males and females, respectively while males were $26.0 \%$ faster than females. When the roll angular magnitude was $9^{\circ}$, individuals' average speed of walking up the staircases was $1.20 \mathrm{~m} / \mathrm{s}$ and $0.83 \mathrm{~m} / \mathrm{s}$ for males and females, respectively, which means that males were $44.6 \%$ faster than females. Individuals' average speed of walking up the staircases was $1.09 \mathrm{~m} / \mathrm{s}$ and $0.97 \mathrm{~m} / \mathrm{s}$ for males and females, respectively, which means that males were $12.4 \%$ faster than females. In the process of walking up and down the staircases, compared with the normal walking mode, gender has a greater influence on an individual's walking speed in the fast walking mode, especially in the process of walking up the staircases. 

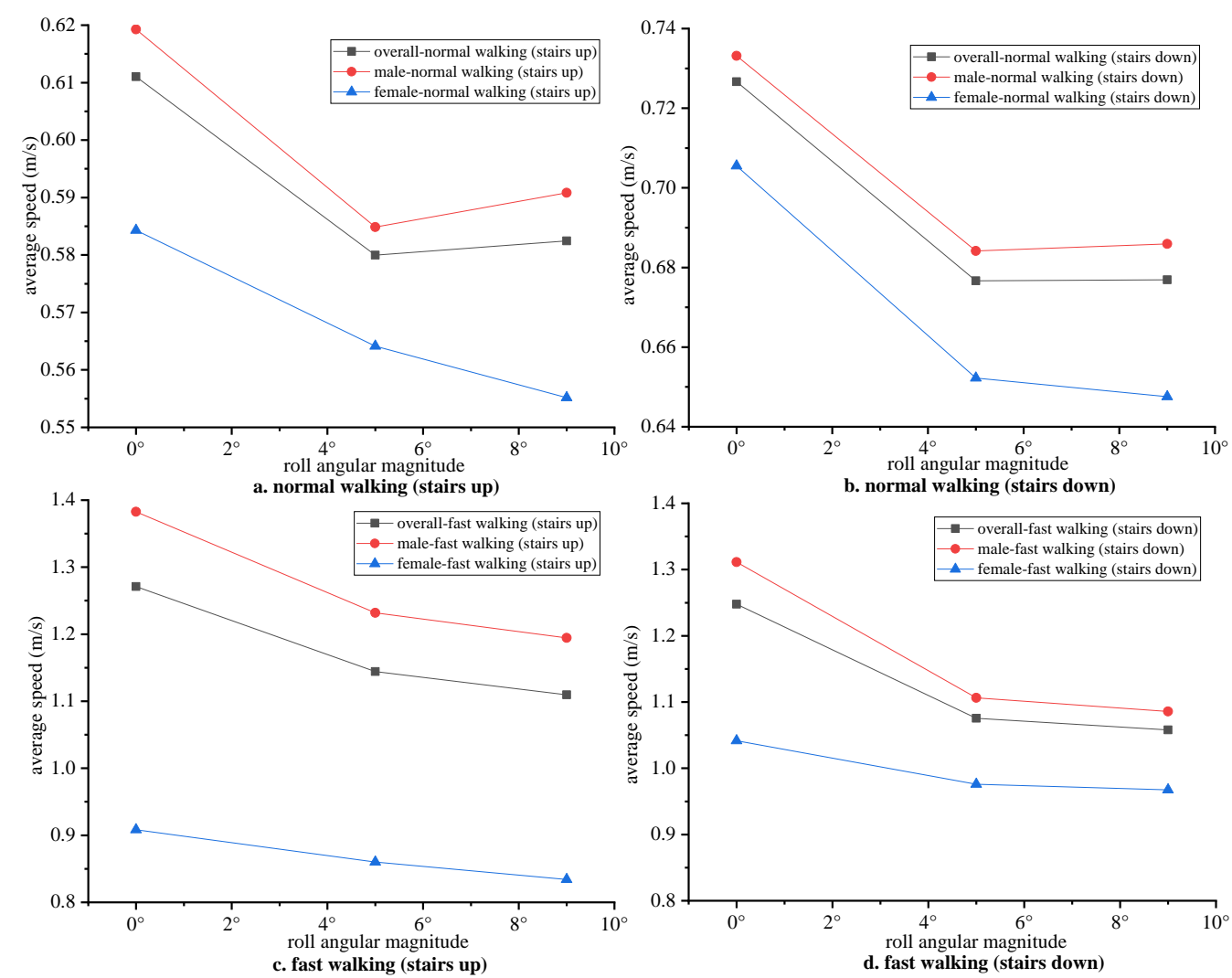

Fig. 11 Comparison of individuals' average walking speeds of males and females

\subsubsection{Comparative analysis of walking speed ratio}

To understand the influence of staircases on an individual's walking speed, the ratio of an individual's average walking speed on the staircases to the one on flat terrain (fore-aft) on the second deck was calculated against different roll angular magnitudes. The results are shown in Fig. 12. The ratio range (due to different angular magnitudes) for the fast walking (up the staircases), fast walking (down the staircases), normal walking (up the staircases) and normal walking (down the staircases) were $66 \%$ to $69 \%$, $62 \%$ to $68 \%, 43 \%$ to $46 \%$ and $51 \%$ to $53 \%$, respectively. This finding also shows that the a staircase had a greater impact on normal walking speed than fast walking, while the impact on the direction of travel (up or down) was not significant. 


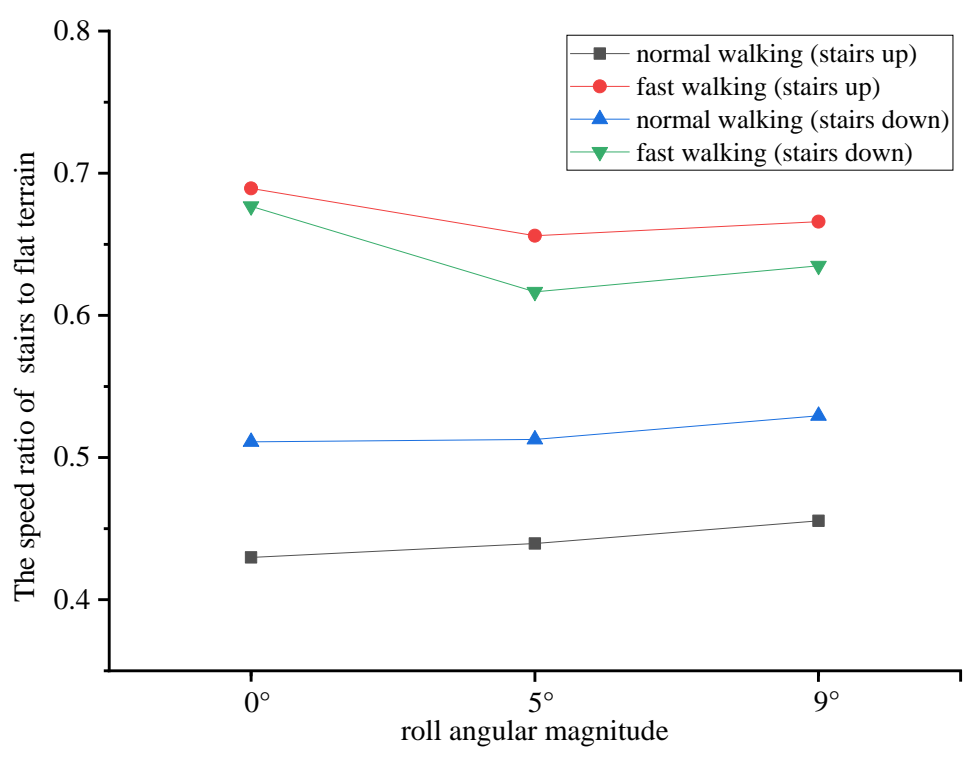

Fig. 12 Individuals' average speed ratio between walking on staircases and flat terrain

\section{Conclusion}

Ship motion is a crucial factor of influencing the safety evacuation of passenger vessels. However, it is very difficult to quantify its effect on individuals' walking speeds and the associated solution still remains unclear in the current literature. In this study, the crewmembers and cadets were invited to participant in a series of walking experiments during their ocean-going internship on a training ship. The data of an individual's walking speed against different ship roll angular magnitudes was collected, and the influence of different ship rolling motions on an individual's walking speed was investigated.

The results show that the average walking speed decreased with an increase in the roll angular magnitude on flat terrains. These findings indicate that ship motion reduced an individual's walking speed on the flat terrains by $7 \%$ to $16 \%$ depending on the roll angular magnitudes. In the same walking mode, the athwartship walking speed was slightly higher than that of the fore-aft one, and the speed on a lower deck was slightly higher than that on an upper deck. In the normal walking (fore-aft) mode, with an increase in the roll angular magnitude, the average walking speed of males decreased from $1.45 \mathrm{~m} / \mathrm{s}$ to $1.29 \mathrm{~m} / \mathrm{s}$ and that of females decreased from $1.32 \mathrm{~m} / \mathrm{s}$ to $1.25 \mathrm{~m} / \mathrm{s}$. The 
average walking speed of males was higher than that of females. With the changed roll angular magnitudes, the walking speed reduction ratio on a lower deck varied from $90 \%$ to $95 \%$. By comparison, the impact of ship motion on walking speed was greater than that of static heeling.

In terms of the staircase scenario, in the normal walking mode, when the roll angular magnitude was $0^{\circ}$, individuals' average speed of walking up the staircases was $0.61 \mathrm{~m} / \mathrm{s}$, and the average speed of walking down the staircases was $0.73 \mathrm{~m} / \mathrm{s}$. The ship motion reduced the speed of walking up the staircases by approximately $5 \%$, and the ship motion had a smaller effect on the walking speed on the staircase than that on flat terrain. When the roll angular magnitude was $0^{\circ}$, the average normal speed of walking down the staircases was approximately $19.7 \%$ faster than that of walking up the staircases. When the roll angular magnitude was $9^{\circ}$, the average normal speed of walking down the staircases was $14.7 \%$ faster than that that of walking up the staircases. The average normal speed of walking up the staircases for males was $5.4 \%$ to $6.9 \%$ faster than that of females, and the average normal speed of walking down the staircases for males was 2.8 to $6.2 \%$ faster than that for females. The influence of the staircases on normal walking was greater than that on fast walking, and the influence on walking up and down the staircases was not significant.

The research results have revealed a high application value. They can be applied in simulation and analysis of ship evacuation and provide reliable empirical data to improve evacuation analysis. However, the results and conclusions are only valid for this experiment or in a similar pedestrian study, as the effect of different test corridor sizes on the experimental results has not been investigated in this study. There are other limitations in this research. Firstly, to avoid disruption to the safe operation of the training ship, only a small number of samples were collected in this study. Secondly, due to the uncontrollable motion state of the ship, this study only collected individuals' walking speeds when the roll angular magnitude of the ship was $9^{\circ}$. Thirdly, due to the limitation of the capacity of the training ship where the personnel on the ship are mostly 
young trainees, the walking speeds of individuals at different age groups were not investigated. Finally, the experimental participants had been familiar with the dynamic environment of the ship to an extent. Compared with those with limited experience onboard, ship rolling may have less influence on the walking speed of the participants.

\section{Acknowledgements}

This work was supported by the National Key R\&D Program of China "Key Technologies and Application Demonstration of Water Emergency Rescue" [grant no. 2018YFC0810402]. This research has received funding from the European Union's Horizon 2020 research and innovation program under the Marie Skłodowska-Curie grant agreement- 840425 .

\section{References}

Bles, W., Nooij, S., \& Boer, L., 2002. Influence of ship listing and ship motion on walking speed, In Pedestrian and Evacuation Dynamics. Springer, Berlin, Germany, pp. 437-452.

Fan, S., Zhang, J., Blanco-Davis, E., Yang, Z., Yan, X., 2020. Maritime accident prevention strategy formulation from a human factor perspective using Bayesian Networks and TOPSIS. Ocean Engineering 210, 107544. https://doi.org/10.1016/i.oceaneng.2020.107544

Galea, E., Grandison, A., Blackshields, D., Sharp, G., Filippidis, L., Deere, S., Nicholls, I., Hifi, Y., Breuillard, A., Cassez, A., 2012. IMO INF Paper Summary-the SAFEGUARD Enhanced Scenarios and Recommendations to IMO to Update MSC Circ 1238.

Glen, I., 2004. BMT fleet technology: conference documentation, 1st International Conference on Escape. Evacuation and Recovery, Lloyd's List.

Haaland, E., Kaipust, J., Wang, Y., Stergiou, N., Stoffregen, T.A., 2015. Human gait at sea while walking fore-aft vs. athwart. Aerospace medicine and human performance 86 (5), 435-439. https://doi.org/10.3357/amhp.4084.2015

Huang, D., Hua, Y., Loughney, S., Blanco-Davis, E., Wang, J., 2020. Lifespan cost analysis of alternatives to global sulphur emission limit with uncertainties. Proceedings of the Institution of Mechanical Engineers, Part M: Journal of Engineering for the Maritime Environment,

1475090220983140.

https://doi.org/10.1177/1475090220983140

IMO, 2016. MSC.1/Circ.1533-Revised Guidelines on Evacuation Analysis for New and Existing Passenger Ships. 
Kim, H., Roh, M.-I., Han, S., 2019. Passenger evacuation simulation considering the heeling angle change during sinking. International Journal of Naval Architecture and Ocean Engineering 11 (1), 329-343. https://doi.org/10.1016/j.ijnaoe.2018.06.007

Kwang-II, H., 2013. An Experiment on Walking Speeds of Freshmen Unexperienced in Shipboard Life on a Passenger Ship. Journal of Navigation and Port Research 37 (3), 239-244. https://doi.org/10.5394/KINPR.2013.37.3.239

Lee, D., Park, J.-H., Kim, H., 2004. A study on experiment of human behavior for evacuation simulation. Ocean Engineering $31 \quad$ (8), 931-941. https://doi.org/10.1016/j.oceaneng.2003.12.003

Meyer-König, T., Valanto, P., Povel, D., 2007. Implementing Ship Motion in AENEAS - Model Development and First Results, in: Waldau, N., Gattermann, P., Knoflacher, H., Schreckenberg, M. (Eds.), Pedestrian and Evacuation Dynamics 2005. Springer Berlin Heidelberg, Berlin, Heidelberg, pp. 429-441.

Montewka, J., Ehlers, S., Goerlandt, F., Hinz, T., Tabri, K., Kujala, P., 2014. A framework for risk assessment for maritime transportation systems - A case study for open sea collisions involving RoPax vessels. Reliability Engineering \& System Safety 124, 142-157. https://doi.org/10.1016/j.ress.2013.11.014

Na W.J., Son B.H., Hong W.H., 2019. Analysis of Walking-speed of Cruise ship Passenger for Effective Evacuation in Emergency. Medico-Legal Update 19, 710-716. https://doi.org/10.5958/0974-1283.2019.00260.3

Sun, J., 2018. Experimental study on passenger movement pattern considering the effect of ship heeling and trim. University of Science and Technology of China. doctoral of engineering.

Sun, J., Guo, Y., Li, C., Lo, S., Lu, S., 2018a. An experimental study on individual walking speed during ship evacuation with the combined effect of heeling and trim. Ocean Engineering 166, 396-403. https://doi.org/10.1016/j.oceaneng.2017.10.008

Sun, J., Lu, S., Lo, S., Ma, J., Xie, Q., 2018b. Moving characteristics of single file passengers considering the effect of ship trim and heeling. Physica A: Statistical Mechanics and its Applications 490, 476-487. https://doi.org/10.1016/j.physa.2017.08.031

Uğurlu, Ö., Y1ldız, S., Loughney, S., Wang, J., 2018. Modified human factor analysis and classification system for passenger vessel accidents (HFACS-PV). Ocean Engineering 161, 47-61. https://doi.org/10.1016/j.oceaneng.2018.04.086

Walter, H., Wagman, J.B., Stergiou, N., Erkmen, N., Stoffregen, T.A., 2017. Dynamic perception of dynamic affordances: walking on a ship at sea. Experimental brain research 235 (2), 517-524. https://doi.org/10.1007/s00221-016-4810-6

Walter, H.J., Li, R., Wagman, J.B., Stoffregen, T.A., 2019. Adaptive perception of changes in affordances for walking on a ship at sea. Human Movement Science 64, 28 37. https://doi.org/10.1016/j.humov.2019.01.002

Wang, H., Liu, Z., Wang, X., Graham, T., Wang, J., 2021a. An analysis of factors affecting the severity of marine accidents. Reliability Engineering \& System Safety 210, 107513. https://doi.org/10.1016/j.ress.2021.107513 
Wang, X., Liu, Z., Wang, J., Loughney, S., Yang, Z., Gao, X., 2021b. Experimental study on individual walking speed during emergency evacuation with the influence of ship motion. Physica A: Statistical Mechanics and its Applications 562, 125369. https://doi.org/10.1016/j.physa.2020.125369

Wang, X., Liu, Z., Wang, J., Loughney, S., Zhao, Z., Cao, L., 2021c. Passengers' safety awareness and perception of wayfinding tools in a Ro-Ro passenger ship during an emergency evacuation. Safety Science 137, 105189. https://doi.org/10.1016/j.ssci.2021.105189

Wang, X., Liu, Z., Zhao, Z., Wang, J., Loughney, S., Wang, H., 2020a. Passengers' likely behaviour based on demographic difference during an emergency evacuation in a Ro$\begin{array}{lllll}\text { Ro passenger ship. Safety } & \text { Science } & 129,\end{array}$ https://doi.org/10.1016/j.ssci.2020.104803

Wang, Y.-F., Wang, L.-T., Jiang, J.-C., Wang, J., Yang, Z.-L., 2020b. Modelling ship collision risk based on the statistical analysis of historical data: A case study in Hong Kong waters. Ocean Engineering 106869. https://doi.org/10.1016/j.oceaneng.2019.106869

Xie, Q., Wang, P., Li, S., Wang, J., Lo, S., Wang, W., 2020a. An uncertainty analysis method for passenger travel time under ship fires: A coupling technique of nested sampling and polynomial chaos expansion method. Ocean Engineering 195, 106604. https://doi.org/10.1016/j.oceaneng.2019.106604

Xie, Q., Zhang, S., Wang, J., Lo, S., Guo, S., Wang, T., 2020b. A surrogate-based optimization method for the issuance of passenger evacuation orders under ship fires. Ocean Engineering 209, 107456. https://doi.org/10.1016/j.oceaneng.2020.107456

Yoshida, K., Murayama, M., Itakaki, T., 2001. Study on evaluation of escape route in passenger ships by evacuation simulation and full-scale trials, In Proceedings 9th Interflame Conference, Citeseer.

Zhang, D., Shao, N., Tang, Y., 2017. An evacuation model considering human behavior, 2017 IEEE 14th International Conference on Networking, Sensing and Control (ICNSC), pp. 54-59.

Zhang, D., Zhao, M., Ying, T., Gong, Y., 2016. Passenger ship evacuation model and simulation under the effects of storms. Systems Engineering - Theory \& Practice 36 (6), 1609-1615. https://doi.org/10.12011/1000-6788(2016)06-1609-07 